\title{
Atmospheric aerosol compositions over the South China Sea: temporal variability and source apportionment
}

\author{
Hong-Wei Xiao ${ }^{1,2}$, Hua-Yun Xiao ${ }^{1,2}$, Li Luo ${ }^{1,2}$, Chun-Yan Shen ${ }^{3}$, Ai-Min Long ${ }^{4,6}$, Lin Chen ${ }^{5}$, Zhen-Hua Long ${ }^{5}$, and \\ Da-Ning $\mathbf{L i}^{5}$ \\ ${ }^{1}$ Laboratory of Atmospheric Environment, Key Laboratory of Nuclear Resources and Environment (Ministry of Education), \\ East China University of Technology, Nanchang 330013, China \\ ${ }^{2}$ School of Water Resources and Environmental Engineering, East China University of Technology, Nanchang 330013, China \\ ${ }^{3}$ College of Fisheries, Guangdong Ocean University, Zhanjiang 524088, China \\ ${ }^{4}$ State Key Laboratory of Tropical Oceanography, South China Sea Institute of Oceanology, Chinese Academy of Sciences, \\ Guangzhou 510301, China \\ ${ }^{5}$ Xisha Deep Sea Marine Environment Observation and Research Station, South China Sea Institute of Oceanology, \\ Chinese Academy of Sciences, Sansha 573199, China \\ ${ }^{6}$ College of Earth Sciences, University of Chinese Academy of Science, Beijing 100049, China
}

Correspondence to: Hua-Yun Xiao (xiaohuayun@ecit.cn) and Li Luo (luoli@ecit.cn)

Received: 4 October 2016 - Discussion started: 7 November 2016

Revised: 20 January 2017 - Accepted: 9 February 2017 - Published: 2 March 2017

\begin{abstract}
In order to evaluate impacts of different source emission on marine atmospheric particles over the South China Sea (SCS), major inorganic ionic concentrations $\mathrm{Na}^{+}, \mathrm{Cl}^{-}, \mathrm{SO}_{4}^{2-}, \mathrm{Ca}^{2+}, \mathrm{Mg}^{2+}, \mathrm{K}^{+}, \mathrm{NH}_{4}^{+}$ and $\mathrm{NO}_{3}^{-}$) were determined in total suspended particulates (TSPs) at Yongxing Island, from March 2014 to February 2015. The annual average concentration of TSPs was $89.6 \pm 68.0 \mathrm{\mu g} \mathrm{m}^{-3}$, with $114.7 \pm 82.1,60.4 \pm 27.0$ and $59.5 \pm 25.6 \mathrm{~g} \mathrm{~m} \mathrm{~m}^{-3}$ in cool, warm and transition seasons, respectively. $\mathrm{Cl}^{-}$had the highest concentration, with an annual average of $7.73 \pm 5.99 \mathrm{~g} \mathrm{~m}^{-3}$, followed by $\mathrm{SO}_{4}^{2-}\left(5.54 \pm 3.65 \mu \mathrm{g} \mathrm{m}^{-3}\right), \mathrm{Na}^{+}\left(4.00 \pm 1.88 \mu \mathrm{g} \mathrm{m}^{-3}\right)$, $\mathrm{Ca}^{2+}\left(2.15 \pm 1.54 \mu \mathrm{g} \mathrm{m}^{-3}\right), \quad \mathrm{NO}_{3}^{-} \quad\left(1.95 \pm 1.34 \mu \mathrm{g} \mathrm{m}^{-3}\right)$, $\mathrm{Mg}^{2+}\left(0.44 \pm 0.33 \mu \mathrm{g} \mathrm{m}^{-3}\right), \mathrm{K}^{+}\left(0.33 \pm 0.22 \mu \mathrm{g} \mathrm{m}^{-3}\right)$ and $\mathrm{NH}_{4}^{+}\left(0.07 \pm 0.07 \mu \mathrm{g} \mathrm{m}^{-3}\right)$. Concentrations of TSPs and the major ions showed seasonal variations, which were higher in the cool season and lower in the warm and transition seasons. Factors of influence were wind speed, temperature, relatively humidity, rain and air mass source region. Back trajectories, concentration-weighted trajectories (CWTs), and positive matrix factorization (PMF) of chemical compositions were analyzed for source apportionment, source contribution and spatiotemporal variation of major ions. Back trajectories and CWTs showed that air masses at Yongxing
\end{abstract}

Island were mainly from the northeast, southwest and southeast in the cool, warm and transition seasons, respectively. The PMF results showed that $77.4 \%$ of $\mathrm{Na}^{+}$and $99.3 \%$ of $\mathrm{Cl}^{-}$were from sea salt; $60.5 \%$ of $\mathrm{NH}_{4}^{+}$was from oceanic emission. Anthropogenic sources were very important for atmospheric aerosols over the island. Secondary inorganic aerosol of $\mathrm{SO}_{2}$ and $\mathrm{NO}_{x}$ from fossil fuel combustion (especially coal in Chinese coastal regions) was the dominant source of $\mathrm{NO}_{3}^{-}(69.5 \%)$ and $\mathrm{SO}_{4}^{2-}(57.5 \%)$.

\section{Introduction}

Aerosols or particulate matters potentially affect global atmospheric processes, chemistry, cloud formation, acid and nutrient deposition in sensitive ecosystems, affect human health as air pollution and have effects on climate (Chin, 2009; Davidson et al., 2005; Deng et al., 2011; S. Liu et al., 2014; Steyn and Chaumerliac, 2016; Zhang et al., 2011). Aerosols have many sources. Primary aerosols, emitted directly from natural and anthropogenic sources, include terrestrial dust from weathering, wind-blown sand and minerals, sea spray, combustion processes and biological emissions (Chin, 2009; Davidson et al., 2005; Rinaldi et al., 2010; 
Pavuluri et al., 2015). There are also secondary aerosols, which form from condensable atmospheric gases, such as $\mathrm{SO}_{2}, \mathrm{NO}_{x}, \mathrm{NH}_{3}$, and volatile organic compounds (Chin, 2009; Kolb and Worsnop, 2013; Xiao et al., 2012a, 2014b; Zhang et al., 2011). Therefore, aerosols are composed of various chemical components (Xiao and Liu, 2004) and contain sulfate, nitrate, ammonium, mineral elements, black carbon and particulate organic matter (Zhang et al., 2007, 2011; Chin, 2009; Pavuluri et al., 2015; Steyn and Chaumerliac, 2016). Because of rapid economic and industrial development in the last few decades in southern and eastern Asia, many aerosols and their precursors released by human activities have become a major environmental problem (Steyn and Chaumerliac, 2016). Aerosols from anthropogenic emissions can be transported long distances from polluted regions to remote open oceans, which is well recognized as a major pathway for the supply of anthropogenic material to ocean surface waters (Duce et al., 2008; Lawrence and Lelieveld, 2010; Jung et al., 2012).

The South China Sea (SCS) is in the tropical-subtropical rim of the northwestern Pacific Ocean and is one of the largest marginal seas in the world (Fig. 1). The SCS is adjacent to several rapidly growing Asian economies, including China, the Philippines, Malaysia, Vietnam and Indonesia (Kim et al., 2014). Consequently, the sea receives substantial amounts of aerosols from surrounding regions through longrange atmospheric transport (Fig. 1; Atwood et al., 2013; Jung et al., 2012). The SCS has a monsoon climate, with a northeast monsoon in boreal winter and spring and a southwest monsoon in boreal summer and autumn (Cui et al., 2016). Thus, aerosol optical thickness (AOT) shows spatial and seasonal variations, with higher AOT in the northern SCS during the boreal cool season and higher AOT in the southern SCS in the boreal warm season (Fig. 1). The SCS receives dust and pollution from the northeast in winter and spring, e.g., from China and Japan (Y. Liu et al., 2014; S.H. Wang et al., 2013; Xiao et al., 2015); during summer and autumn, the SCS receives particulate and gas phase pollutants from biomass burning in the southwest of SCS, e.g., from Malaysia and Indonesia (Atwood et al., 2013). However, the observational data on aerosol chemistry over the SCS are very sparse (Xiao et al., 2015).

To get better understanding of potential sources, source contributions and spatiotemporal variations of marine aerosols over the SCS, total suspended particulates (TSPs) were continuously collected at Yongxing Island from March 2014 to February 2015. The concentrations of major inorganic water-soluble ions were determined. Furthermore, back trajectory, concentration-weighted trajectory (CWT) and positive matrix factorization (PMF) analyses were also used to identify and apportion the main sources of aerosols and their chemical composition over the SCS.

\section{Materials and methods}

\subsection{Study site}

Aerosol samples were collected from March 2014 to February 2015 on the rooftop of Xisha Deep Sea Marine Environment Observation and Research Station, South China Sea Institute of Oceanology, Chinese Academy of Sciences (SCSIO-CAS). This station is at the Yongxing Island (YXI; Fig. $1 ; 16.83^{\circ} \mathrm{N}, 112.33^{\circ} \mathrm{E}$ ). This island has a tropical monsoon climate, with northeast monsoons in winter and spring, and southwest monsoons in summer and autumn (Xiao et al., 2015). The island is located in the high aerosol concentrations area of the northern SCS during winter and spring, and also at the periphery of the high concentrations area of the southern SCS during summer and autumn (Fig. 1). Therefore, pollutants can arrive from northeastern Asia in winter and spring, and Southeast Asia in summer and autumn (Y. Liu et al., 2014; S.-H. Wang et al., 2013; Xiao et al., 2015; Atwood et al., 2013). It is also influenced by local SCS marine sources. More information about Yongxing Island is given elsewhere (Xiao et al., 2015, 2016). In the present study, the sampling period was divided into three seasons based on wind direction and back trajectories. The cool season was March, April, October, November, December 2014 and January, February 2015, with principal air masses from the northeast and $25.9^{\circ} \mathrm{C}$ in temperature, and the warm season was June-September 2014, with air masses primarily from the southwest and $29.7^{\circ} \mathrm{C}$ in temperature. The transition season was May 2014, with local and short air masses primarily from the southeast. Yongxing Island has an annual average temperature of $27.7 \pm 2.7^{\circ} \mathrm{C}$, relative humidity (RH) of $80 \pm 7 \%$ and wind speeds of $3.6 \pm 1.8 \mathrm{~m} \mathrm{~s}^{-1}$. There were strong seasonal variations between March 2014 and February 2015 (Fig. 2). Accumulated annual rainfall was $1526 \mathrm{~mm}$ during this period, with about $30 \%$ occurring in the cool season (Fig. 2).

In order to identify the effect of sulfate, dust and smoke on Yongxing Island, we obtain NAAPS Global Aerosol Model data (gif format, https://www.nrlmry.navy. mil/aerosol/\#aerosolobservations) between March 2014 and February 2015 to synthesize 1 year of the picture (gif format; Fig. S1 in the Supplement).

\subsection{Sample collection and chemical analyses}

Aerosol was collected on quartz filters using a special highflow rate $\left(1.05 \pm 0.03 \mathrm{~m}^{3} \mathrm{~min}^{-1}\right) \mathrm{KC}-1000$ sampler, which was installed $1 \mathrm{~m}$ above the building's (about $15 \mathrm{~m}$ ) roof surface of the station of SCSIO-CAS. The sampling time was nominally $96 \mathrm{~h}$ (4 days one sample). All samples were stored in a refrigerator at $-20^{\circ} \mathrm{C}$ until analysis in the laboratory. In the laboratory, one-eighth filters were cut and placed in a clean $50 \mathrm{~mL}$ Nalgene tube with additional ultrapure water. The extract was filtered using pinhole filters, which were then 


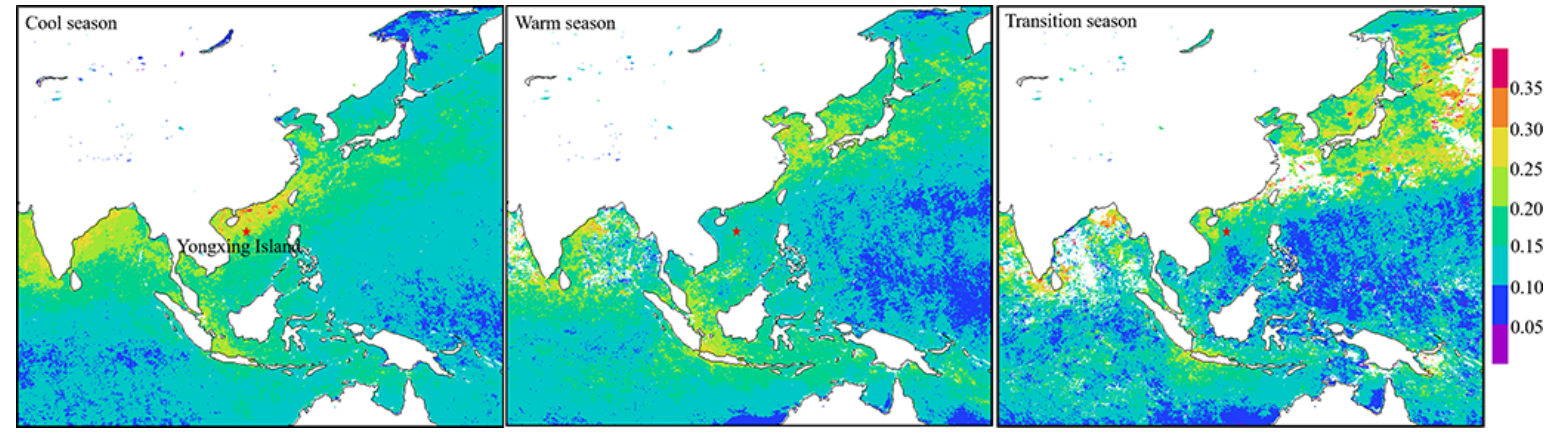

Figure 1. Distribution of seasonal average aerosol optical thickness (AOT) at $550 \mathrm{~nm}$ (T550) over northwestern Pacific in cool, warm and transition seasons during sampling period. Monthly AOT products (from Moderate Resolution Imaging Spectrometer, MODIS) with $4 \mathrm{~km}$ resolution were downloaded from GlobColour (http://hermes.acri.fr/). The GlobColour project began in 2005 as an ESA Data User Element project to provide a continuous dataset of merged level 3 ocean color products.

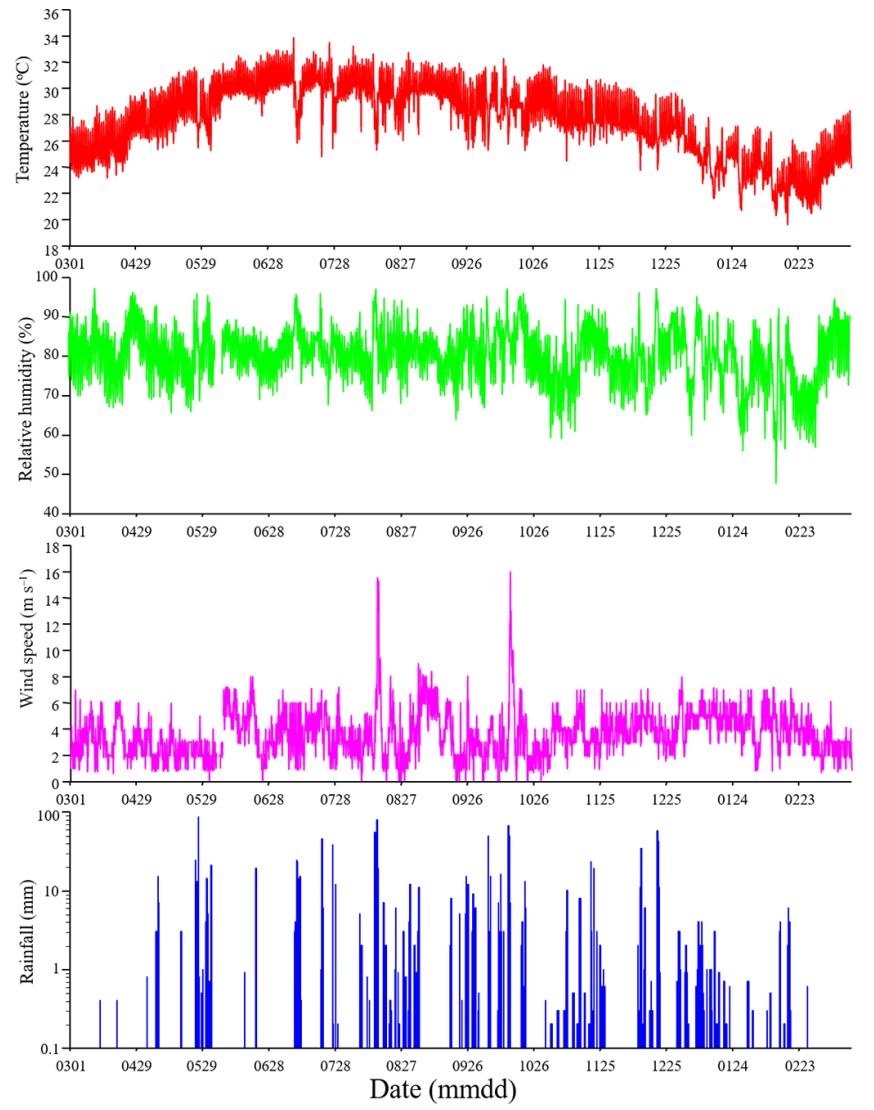

Figure 2. $3 \mathrm{~h}$ temperature, relative humidity, wind speed and precipitation at Yongxing Island during sampling period (March 2014 to February 2015).

rinsed twice with $5 \mathrm{~mL}$ ultrapure water. The extract and rinse were put into $50 \mathrm{~mL}$ tubes together and stored in a refrigerator at $-20^{\circ} \mathrm{C}$ until chemical analyses. Aerosol water-soluble major anion concentrations $\left(\mathrm{F}^{-}, \mathrm{Cl}^{-}, \mathrm{NO}_{3}^{-}, \mathrm{SO}_{4}^{2-}, \mathrm{Br}^{-}\right)$ were determined by ICS-90 ion chromatography (Dionex, California, USA), and water-soluble metal and non-metal el- emental concentrations (Al, $\mathrm{Ca}, \mathrm{Fe}, \mathrm{K}, \mathrm{Mg}, \mathrm{Mn}, \mathrm{Na}, \mathrm{SiO}_{2}$, $\mathrm{Sr}$ ) were analyzed by an inductively coupled plasma optical emission spectrometer (ICP-OES; Vista-MPX, CA, USA); the $\mathrm{NH}_{4}^{+}$concentration was determined by spectrophotometry after treatment with Nessler's reagent, as described in detail information in the Supplement Sect. S1.

\subsection{Sea salt and non-sea salt contributions}

In order to determine the source contributions to the ionic compositions in TSPs, the sea salt ion (SS) and the non-sea salt ion (NSS), are calculated using $\mathrm{Na}$ as a reference element for marine origin by the following equations (Eqs. 1 and 2; Xiao et al., 2013):

$\mathrm{SS}(\%)=100\left(X / \mathrm{Na}^{+}\right)_{\text {sea }} /\left(X / \mathrm{Na}^{+}\right)_{\mathrm{TSPs}}$,

$\operatorname{NSS}(\%)=100-\mathrm{SS}$,

where $X$ represents the ionic composition and the data of $\left(X / \mathrm{Na}^{+}\right)_{\text {sea }}$ come from Keene et al. (1986).

\subsection{Back trajectories and concentration-weighted trajectories analysis}

Back trajectories and CWTs are used to determine the longdistance transport of atmospheric pollutants and regional source areas by the program of TrajStat (version 1.2.26) (Cheng et al., 2013; Wang et al., 2009; Xiao et al., 2014a, 2015). For each day, 10-day ( $240 \mathrm{~h}$ ) back trajectories of air masses (Pavuluri et al., 2015) arriving at Yongxing Island were computed, with the top of the model set to $1000 \mathrm{~m}$ above sea level (Xiao et al., 2015). In CWT model, each grid cell receives a weighted concentration obtained by averaging sample concentrations that have associated trajectories crossing the grid cell (Xiao et al., 2015). The detail methods are described in Supplement Sect. S2. 


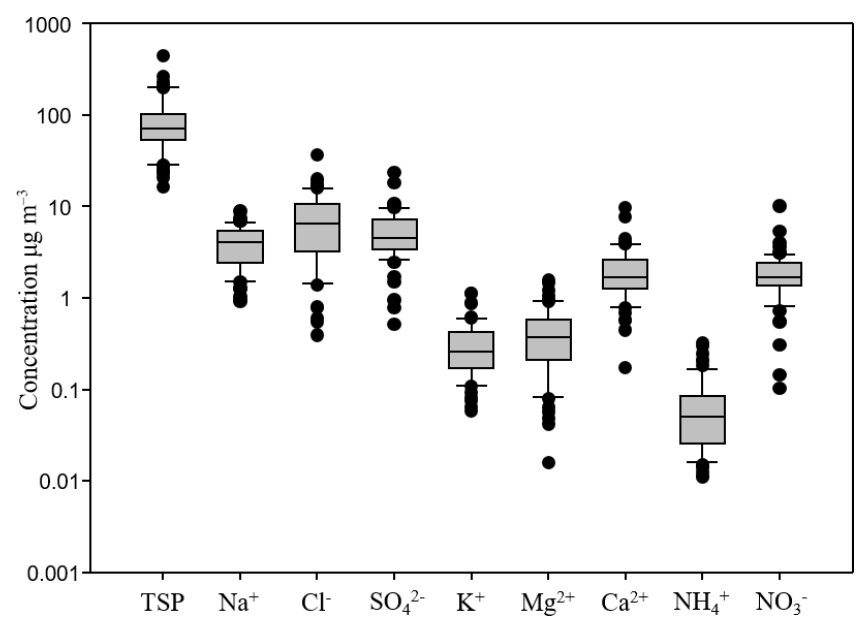

Figure 3. Annual average mass concentrations of aerosol chemical species at Yongxing Island. Box boundary indicates 25th and 75th percentile. Lines within the box show the mean. Whiskers above and below the box indicate 90th and 10th percentiles.

\subsection{Positive matrix factorization model}

Receptor models are used to quantify the contributions of sources based on the composition or fingerprints of the sources (Norris et al., 2014). The PMF is an effective source apportionment receptor model that does not require source profiles prior to analysis and has no limitation on source numbers (Crippa et al., 2013; Tiwari et al., 2013; Zhang et al., 2011, 2015). In our study, EPA PMF 5.0 was used to determine source apportionment of each major ion. The detail methods were described in Supplement Sect. S3.

\section{Results and discussion}

\subsection{Aerosol chemical composition over the SCS and comparison with global marine aerosols}

\subsubsection{Aerosol characteristics over the SCS}

Figures 3, 4 and Table 1 provide information on atmospheric concentrations of TSPs and major inorganic ions during the sampling period at Yongxing Island. The annual average TSP concentrations at the island were $89.6 \pm 68.0 \mu \mathrm{g} \mathrm{m}^{-3}$, with a range of 16.4 to $440.1 \mu \mathrm{g} \mathrm{m}^{-3}$. The major inorganic ionic concentrations $\left(\mathrm{Na}^{+}, \mathrm{Cl}^{-}, \mathrm{SO}_{4}^{2-}, \mathrm{Ca}^{2+}, \mathrm{Mg}^{2+}, \mathrm{K}^{+}, \mathrm{NH}_{4}^{+}\right.$ and $\mathrm{NO}_{3}^{-}$) accounted for $24.8 \%$ of TSPs. Total major inorganic ionic concentrations were $22.21 \mu \mathrm{g} \mathrm{m}^{-3} \cdot \mathrm{Cl}^{-}$had the highest concentration among these ions, from 0.39 to $36.47 \mu \mathrm{g} \mathrm{m}^{-3}$, with an annual average of $7.73 \pm 5.99 \mu \mathrm{g} \mathrm{m}^{-3}$. It was followed by $\mathrm{SO}_{4}^{2-}$ (range $0.52-23.34 \mu \mathrm{g} \mathrm{m}^{-3}$; average $\left.5.54 \pm 3.65 \mathrm{\mu g} \mathrm{m}^{-3}\right), \mathrm{Na}^{+}\left(0.9-8.86 \mu \mathrm{g} \mathrm{m}^{-3}\right.$; average $\left.4.00 \pm 1.88 \mu \mathrm{g} \mathrm{m}^{-3}\right), \mathrm{Ca}^{2+}\left(0.17-9.65 \mu \mathrm{g} \mathrm{m}^{-3}\right.$; average $\left.2.15 \pm 1.54 \mu \mathrm{g} \mathrm{m}^{-3}\right), \mathrm{NO}_{3}^{-}\left(0.10-10.05 \mu \mathrm{g} \mathrm{m}^{-3}\right.$; aver- age $\left.1.95 \pm 1.34 \mu \mathrm{g} \mathrm{m}^{-3}\right), \mathrm{Mg}^{2+}\left(0.02-1.55 \mu \mathrm{g} \mathrm{m}^{-3}\right.$; average $\left.0.44 \pm 0.33 \mu \mathrm{g} \mathrm{m}^{-3}\right), \mathrm{K}^{+}\left(0.06-1.13 \mu \mathrm{g} \mathrm{m}^{-3}\right.$; average $\left.0.33 \pm 0.22 \mu \mathrm{g} \mathrm{m}^{-3}\right)$ and $\mathrm{NH}_{4}^{+}\left(0.01-0.32 \mu \mathrm{g} \mathrm{m}^{-3}\right.$; average $0.07 \pm 0.07 \mu \mathrm{g} \mathrm{m}^{-3}$ ).

\subsubsection{Aerosols over SCS compared with global marine aerosols}

The annual average TSP concentrations at Yongxing Island is also lower than the annual average value over the northern Yellow Sea $\left(123.2 \mu \mathrm{g} \mathrm{m}^{-3}\right)$, another Chinese marginal sea (L. Wang et al., 2013). However, the mean TSP concentrations at Yongxing Island are not lower than those at other remote islands or other seas, such as the Indian Ocean $\left(21.1 \mu \mathrm{g} \mathrm{m}^{-3}\right)$, Pacific Ocean $\left(36.7 \mu \mathrm{g} \mathrm{m}^{-3}\right)$, Mediterranean Sea $\left(46.9 \mu \mathrm{g} \mathrm{m}^{-3}\right)$, South Atlantic $\left(39.1 \mu \mathrm{g} \mathrm{m}^{-3}\right)$ and three islands of Okinawa $\left(22.6 \mu \mathrm{g} \mathrm{m}^{-3}\right.$ in summer and $44.5 \mu \mathrm{g} \mathrm{m}^{-3}$ in spring) (Arakaki et al., 2014; Balasubramanian et al., 2013; Zhang et al., 2010).

The aforementioned annual average TSP and ionic concentrations are comparable to those reported in many remote oceans (Fig. 5), e.g., Hedo, which is at the junction of the East China Sea and northwestern Pacific. The marine ions $\left(\mathrm{Na}^{+}\right.$and $\left.\mathrm{Cl}^{-}\right)$accounted for $53 \%$ of total major ions (Fig. 4). $\mathrm{Na}^{+}$and $\mathrm{Cl}^{-}$concentrations at Yongxing Island were higher than most reported values among all locations and remote sites (Fig. 5), such as the Indian Ocean (3.0 and $4.4 \mu \mathrm{g} \mathrm{m}^{-3}$, respectively), Arabian Sea (1.9 and $2.2 \mu \mathrm{g} \mathrm{m}^{-3}$, respectively), Oki (3.3 and $4.3 \mu \mathrm{g} \mathrm{m}^{-3}$, respectively) and Rishiri islands (1.2 and $2.7 \mu \mathrm{g} \mathrm{m}^{-3}$, respectively) in the Sea of Japan, Amsterdam Island (1.4 and $2.3 \mu \mathrm{g} \mathrm{m}^{-3}$, respectively) in the Southern Ocean, Bermuda (3.3 and $4.8 \mu \mathrm{g} \mathrm{m}^{-3}$, respectively) in the Atlantic Ocean and Hawaii (0.5 and $0.4 \mathrm{\mu g} \mathrm{m}^{-3}$, respectively) in the Pacific (Kumar et al., 2008; Okuda et al., 2006; Claeys et al., 2010; Moody et al., 2014; Carrillo et al., 2002). However, $\mathrm{Na}^{+}$and $\mathrm{Cl}^{-}$concentrations were lower than samples from cruises, such as over the North Atlantic 2 (7.0 and $9.6 \mu \mathrm{g} \mathrm{m}^{-3}$, respectively) and Pacific (5.8 and $9.0 \mu \mathrm{g} \mathrm{m}^{-3}$, respectively) (Zhang et al., 2010). The $\mathrm{Ca}^{2+}$ concentration was the highest among all locations and contributes $10 \%$ of major ions (Fig. 4), followed by the Mediterranean Sea, South Atlantic and North Atlantic 2 (Fig. 5). The relatively high $\mathrm{Ca}^{2+}$ concentration may be because of Asian terrestrial dust transported to Yongxing Island. NSS $\mathrm{Ca}^{2+}$ accounted for $93 \%$ of total $\mathrm{Ca}^{2+}$, ranging from 0.14 to $9.31 \mu \mathrm{g} \mathrm{m}^{-3}$ with an annual average of $1.99 \mu \mathrm{g} \mathrm{m}^{-3}$. Large contributions of NSS Ca ${ }^{2+}$ were also found in the Mediterranean Sea, South Atlantic and North Atlantic 2, being at 88.4, 90.3 and $90.0 \%$, respectively (Zhang et al., 2010). The relatively high NSS-Ca ${ }^{2+}$ concentrations in those oceans were potentially from the crust or dust from some deserts (Zhang et al., 2010). Comparing Yongxing Island with all locations, average $\mathrm{Mg}^{2+}$ concentrations were higher at Yongxing Island than most reported values among all locations (Fig. 5). $\mathrm{K}^{+}$was also the highest among all locations (Fig. 5). 

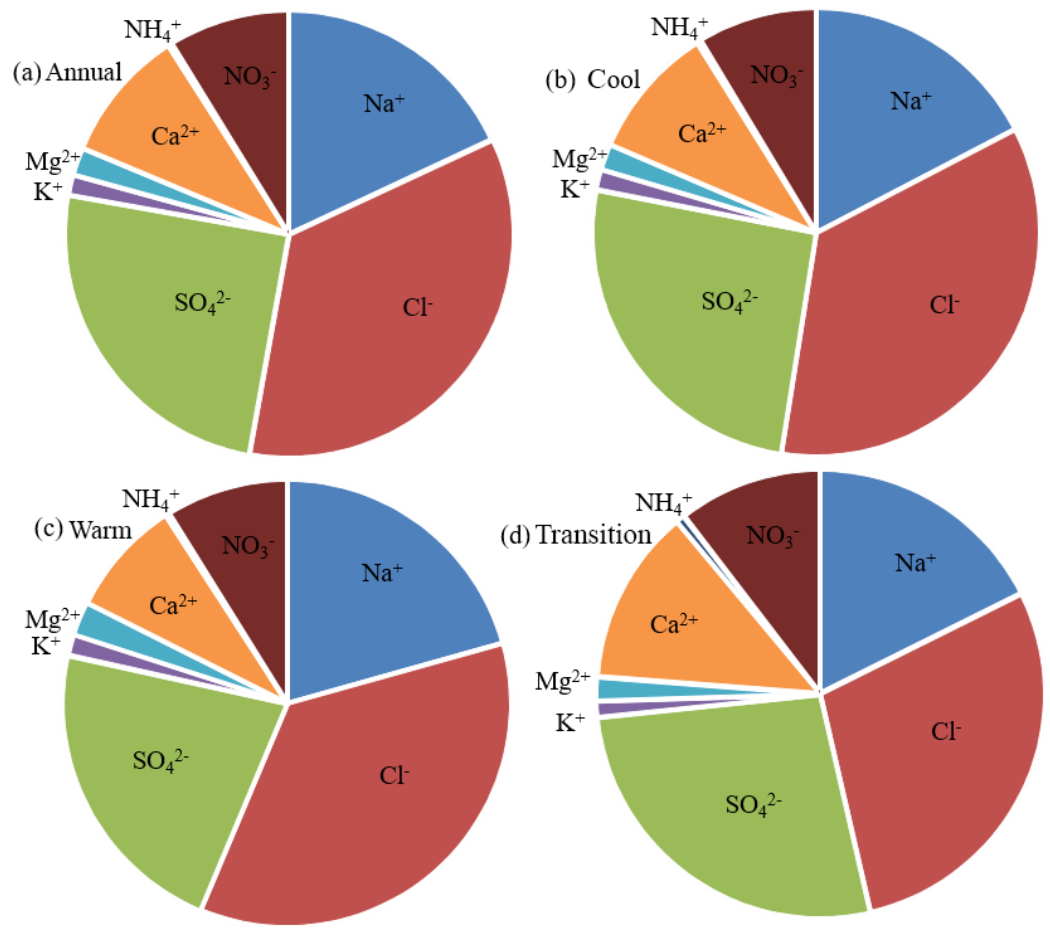

Figure 4. Mean contributions of each major ionic component to total ionic mass concentration of (a) Yongxing Island (YXI) annual, (b) YXI cool season, (c) YXI warm season and (d) YXI transition season.

Table 1. Annual average, minimum and maximum mass concentrations $\left(\mu \mathrm{g} \mathrm{m}^{-3}\right)$ of TSPs and aerosol chemical species at Yongxing Island.

\begin{tabular}{lrrrrrrrrr}
\hline & $\mathrm{TSPs}$ & $\mathrm{Na}^{+}$ & $\mathrm{Cl}^{-}$ & $\mathrm{K}^{+}$ & $\mathrm{Ca}^{2+}$ & $\mathrm{Mg}^{2+}$ & $\mathrm{SO}_{4}^{2-}$ & $\mathrm{NO}_{3}^{-}$ & $\mathrm{NH}_{4}^{+}$ \\
\hline Annual & $89.6 \pm 68.0$ & $4.00 \pm 1.88$ & $7.73 \pm 5.99$ & $0.33 \pm 0.22$ & $2.15 \pm 1.54$ & $0.44 \pm 0.33$ & $5.54 \pm 3.65$ & $1.95 \pm 1.34$ & $0.07 \pm 0.07$ \\
Minimum & 16.4 & 0.90 & 0.39 & 0.06 & 0.17 & 0.02 & 0.52 & 0.10 & 0.01 \\
Maximum & 440.1 & 8.86 & 36.47 & 1.13 & 9.65 & 1.55 & 23.34 & 10.05 & 0.32 \\
\hline
\end{tabular}

$\mathrm{NSS} \mathrm{K}^{+}$ranged from 0 to $0.87 \mu \mathrm{g} \mathrm{m}^{-3}$, with an annual average of $0.18 \mu \mathrm{g} \mathrm{m}^{-3}$ and a contribution of $55 \%$ to total watersoluble $\mathrm{K}^{+}$at Yongxing. In general, $\mathrm{SO}_{4}^{2-}, \mathrm{NO}_{3}^{-}$and $\mathrm{NH}_{4}^{+}$ were major in the form of secondary inorganic aerosols. They accounted for only $34.0 \%$ of total inorganic ionic concentrations, giving them an intermediate position among all locations (Fig. 5). The average $\mathrm{SO}_{4}^{2-}$ concentration at Yongxing was the highest among all locations. As shown in Fig. 4, the mean contribution of $\mathrm{SO}_{4}^{2-}$ to major inorganic ionic components was $\sim 25 \%$ at Yongxing. The NSS-SO ${ }_{4}^{2-}$ concentration was $3.66 \mu \mathrm{g} \mathrm{m}^{-3}$, with a contribution of $66.1 \%$ to total $\mathrm{SO}_{4}^{2-}$. Similar to $\mathrm{SO}_{4}^{2-}$, the average concentration of $\mathrm{NO}_{3}^{-}$in this study was the highest among all locations. It accounted for $9 \%$ of major ions at Yongxing Island. This indicates that a large number of anthropogenic sources affected the concentrations of $\mathrm{SO}_{4}^{2-}$ and $\mathrm{NO}_{3}^{-}$. It was surprising that $\mathrm{NH}_{4}^{+}$had relatively low concentrations over most oceans, except for the South Atlantic and Mediterranean Sea (Fig. 5). The average $\mathrm{NH}_{4}^{+}$concentration was $0.07 \pm 0.07 \mu \mathrm{g} \mathrm{m}^{-3}$ in aerosol at Yongxing Island (Fig. 3), representing $<1 \%$ of total major ions (Fig. 4). Further, low concentrations of $\mathrm{NH}_{4}^{+}$were also observed in rainwater on the island (Xiao et al., 2016).

\subsubsection{Global marine aerosol chemical patterns}

Globally, sea salt ions $\left(\mathrm{Na}^{+}\right.$and $\left.\mathrm{Cl}^{-}\right)$were the most important components in marine atmospheric aerosol, with higher concentration of $\mathrm{Cl}^{-}$than $\mathrm{Na}^{+}$, except over the Mediterranean and northern seas (Fig. 5; Zhang et al., 2010; Ebert et al., 2000). In the marine atmosphere, sea salt aerosol $(\mathrm{NaCl})$ can react with sulfuric acid and nitric acid to release $\mathrm{HCl}$, which results in a deficit of $\mathrm{Cl}^{-}$relative to $\mathrm{Na}^{+}$(Zhang et al., 2010). It is also found that a deficit of $\mathrm{Cl}^{-}$in transition season at Yongxing Island (Fig. 4 and Table 2) was most likely because air masses were primarily from remote ocean regions far from the continent (Fig. 1), where wind is weak (Fig. 2). The mole equivalent ratios of $\mathrm{Cl}^{-} / \mathrm{Na}^{+}$(neq $\mathrm{L}^{-1}$ ) in aerosols were slightly larger than seawater in annual, cool and warm seasons at Yongxing Island (Table 2). This suggests that $\mathrm{Cl}^{-}$enrichment had an anthropogenic or other nat- 


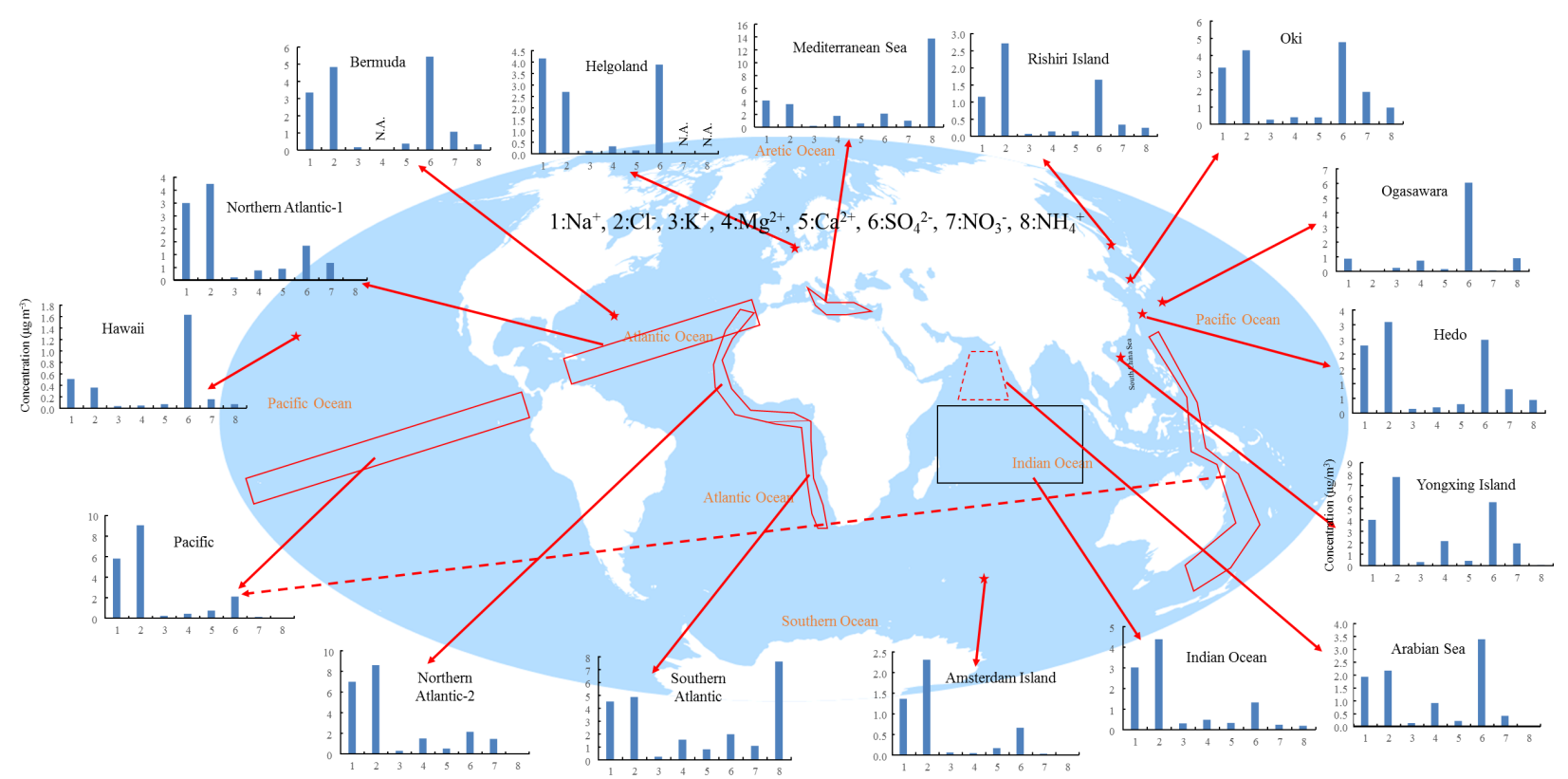

Figure 5. Comparisons of major ions in aerosol at Yongxing Island with global ocean. Data of Oki, Ogasawara and Hedo are from EANET (www.eanet.asia); data of Rishiri Island are from Okuda et al. (2006); data of Hawaii are from Carrillo et al. (2002); data of Bermuda are from Moody et al. (2014); data of Amsterdam Island are from Claeys et al. (2010); data of the Arabian Sea and Indian Ocean are from Kumar et al. (2008); data of Helgoland are from Ebert et al. (2000); and data of the Mediterranean Sea, North Atlantic 1 and 2, Pacific and South Atlantic are from Zhang et al. (2010). Pentagrams represent sampling sites on islands while others represent cruises. N.A. indicates no data.

Table 2. Mole equivalent ratios for major ionic species in aerosols at Yongxing Island (annual, cool, transition and warm seasons), together with seawater ratios for comparison.

\begin{tabular}{lrrrrr}
\hline & \multicolumn{4}{c}{ Yongxing Island } & \multirow{2}{*}{ Seawater* } \\
\cline { 2 - 5 } & annual & \multicolumn{1}{c}{ cool } & transition & warm & \\
\hline $\mathrm{Cl}^{-} / \mathrm{Na}^{+}$ & 1.25 & 1.31 & 1.06 & 1.12 & 1.17 \\
$\mathrm{Mg}^{2+} / \mathrm{Na}^{+}$ & 0.21 & 0.21 & 0.19 & 0.23 & 0.22 \\
$\mathrm{~K}^{+} / \mathrm{Na}^{+}$ & 0.048 & 0.051 & 0.040 & 0.042 & 0.021 \\
$\mathrm{Ca}^{2+} / \mathrm{Na}^{+}$ & 0.62 & 0.64 & 0.83 & 0.47 & 0.044 \\
$\mathrm{SO}_{4}^{2-} / \mathrm{Na}^{+}$ & 0.66 & 0.71 & 0.73 & 0.51 & 0.12 \\
$\mathrm{NSS} \mathrm{SO}_{4}^{2-} / \mathrm{Na}^{+}$ & 0.54 & 0.58 & 0.61 & 0.39 & - \\
$\mathrm{NO}_{3}^{-} / \mathrm{Na}^{+}$ & 0.18 & 0.18 & 0.22 & 0.16 & - \\
$\mathrm{NH}_{4}^{+} / \mathrm{Na}^{+}$ & 0.022 & 0.021 & 0.044 & 0.016 & - \\
$\mathrm{NO}_{3}^{-} / \mathrm{NSS} \mathrm{SO}_{4}^{2-}$ & 0.34 & 0.32 & 0.36 & 0.41 & - \\
$\mathrm{NH}_{4}^{+} / \mathrm{NSS} \mathrm{Ca}^{2+}$ & 0.038 & 0.035 & 0.056 & 0.038 & - \\
\hline
\end{tabular}

* Seawater ratios from Keene et al. (1986).

ural origin (Duan et al., 2006; Jung et al., 2012; Xiao et al., 2013). For $\mathrm{SO}_{4}^{2-}$ with $\mathrm{SS} \mathrm{SO}_{4}^{2-}$ and $\mathrm{NSS} \mathrm{SO}_{4}^{2-}$, $\mathrm{NSS} \mathrm{SO}_{4}^{2-}$ was greatly influenced by anthropogenic sources from developed industrial areas, leading to higher concentrations of $\mathrm{SO}_{4}^{2-}$ than $\mathrm{Na}^{+}$and $\mathrm{Cl}^{-}$. Examples were Bermuda, Ogasawara and the Arabian Sea (Fig. 5; Moody et al., 2014; Kumar et al., 2008), where NSS SO 4 - was the preferred species for acid displacement (Zhang et al., 2010). As another important ion of anthropogenic sources, $\mathrm{NO}_{3}^{-}$concentrations were often good relationships with those of $\mathrm{NSS} \mathrm{SO}_{4}^{2-}$ (Zhang et al., 2010), with relatively high concentrations among major ions (Fig. 5). Relatively high concentrations of $\mathrm{SO}_{4}^{2-}$ and $\mathrm{NO}_{3}^{-}$were also found over the SCS (Figs. 3 and 4). $\mathrm{NH}_{4}^{+}$had the lowest concentrations among the major ions in most marine atmospheric aerosols, suggesting little ammonia transport to the open ocean, such as Yongxing Island. However, there were some exceptions. For example, the South Atlantic and Mediterranean Sea had the highest $\mathrm{NH}_{4}^{+}$concentrations among major ions (Fig. 5). Over most seas, the order was $\mathrm{Ca}^{2+}>\mathrm{Mg}^{2+}>\mathrm{K}^{+}$. However, we found that $\mathrm{Mg}^{2+}$ had higher concentrations than $\mathrm{Ca}^{2+}$ in some remote ocean areas, such as in the Pacific, Atlantic and Southern oceans (Zhang et al., 2010). This indicates that $\mathrm{Ca}^{2+}$ of crustal origin was difficult to transport to the remote oceans, and $\mathrm{Mg}^{2+}$ may mainly be from sea salt over the open ocean (Moody et al., 2014).

\subsection{Seasonal patterns of aerosol chemical species over SCS and adjacent areas}

\subsubsection{Seasonal characteristics at Yongxing Island}

As illustrated in Figs. 4 and 6, seasonal and monthly TSP concentrations and major inorganic water-soluble ion concentrations had distinct features at Yongxing Island. Generally, concentrations of TSPs and major inorganic ions were higher in the cool season than in the warm season (Fig. 6). 

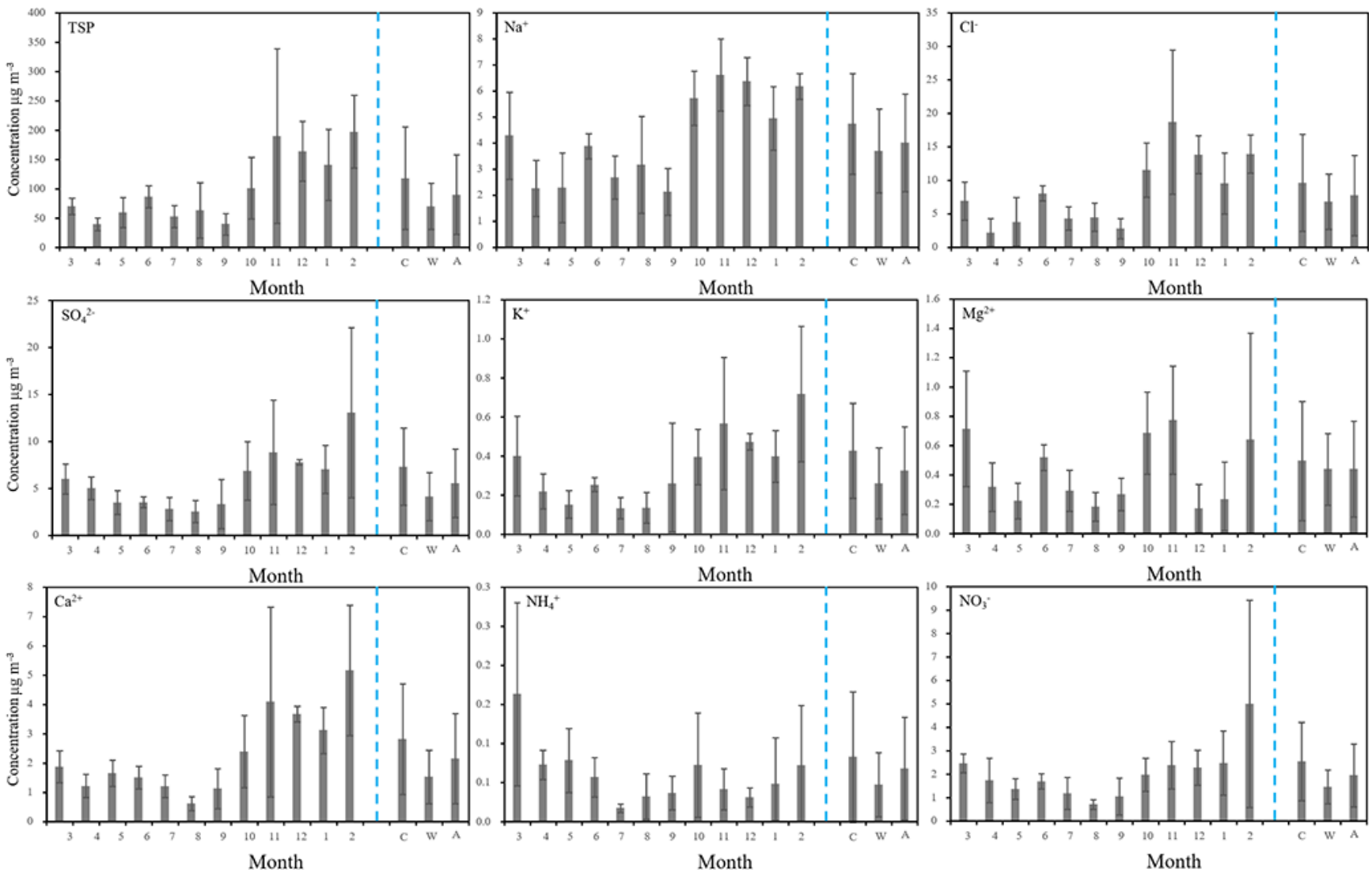

Figure 6. Seasonal variations of TSP mass concentrations and associated species, including $\mathrm{Na}^{+}, \mathrm{Cl}^{-}, \mathrm{SO}_{4}^{2-}, \mathrm{Mg}^{2+}, \mathrm{K}^{+}, \mathrm{Ca}^{2+}, \mathrm{NH}_{4}^{+}$and $\mathrm{NO}_{3}^{-}$at Yongxing Island (cool season: C; warm season: W; annual: A). Shown are the mean and standard deviation for each bar.

Seasonal variations were the same as those in other studies, such as Okinawa, and 18 urban, rural and remote sites in various regions of China (Arakaki et al., 2014; Wang et al., 2006; Xiao and Liu, 2004; Zhang et al., 2012).

Average TSP concentrations were $114.7 \pm 82.1$, $60.4 \pm 27.0$ and $59.5 \pm 25.6 \mu \mathrm{g} \mathrm{m}^{-3}$ in the cool, warm and transition seasons, respectively, with the highest monthly average in November 2014 and the lowest in April $\left(39.4 \mathrm{\mu g} \mathrm{m}^{-3}\right)$ and September $\left(39.9 \mu \mathrm{g} \mathrm{m}^{-3}\right)$ of the same year (Fig. 6). There were lower concentrations in the warm season than in the cool season because $70 \%$ of rainfall at Yongxing Island happens during the warm season (Fig. 2), being the same as other studies, such as Shanghai and over the China Sea (Wang et al., 2006; Zhao et al., 2015). The positive correlation between TSP concentrations and wind speed $(p<0.01)$ shown in Table 3 suggests that relatively high speeds can produce many particles from both sea spray and terrigenous matter. We discovered negative correlations between TSP concentrations and temperature $(p<0.01)$ and relatively humidity $(p<0.01)$ (Table 2$)$, indicating that warm temperatures and high relatively humidity enhance particle activation and scavenging is happening (Liu et al., 2011).
As shown in Figs. 4 and 6, sea salt ions $\mathrm{Na}^{+}$and $\mathrm{Cl}^{-}$ were characterized by a gradual increase from the transition to cool season. Their concentrations (in $\mu \mathrm{g} \mathrm{m}^{-3}$ ) in the cool, warm and transition seasons were $4.91 \pm 1.82$ and $3.04 \pm 1.08,2.28 \pm 1.35$ and $9.93 \pm 6.78$, and $5.25 \pm 2.63$ and $3.73 \pm 3.63$, respectively, with corresponding contributions of 52, 57 and $57 \%$ to total major ions in those seasons. The highest $\mathrm{Na}^{+}$and $\mathrm{Cl}^{-}$concentrations in a single sample were found in November, with the lowest concentrations in May and April, respectively. The highest average monthly concentrations were in November. Positive relationships between $\mathrm{Na}^{+}$or $\mathrm{Cl}^{-}$and wind speed in Table $3(p<0.01$, correlation coefficient $R=0.44$ and $p<0.01, R=0.43$, respectively) at Yongxing Island suggest that sea salt concentrations were dependent on wind speed. This is consistent with results at Chichijima Island (Boreddy and Kawamura, 2015). There was a low negative relationship between $\mathrm{Na}^{+}$ and rainfall $(p<0.05, R=0.27)$ but no relationship between $\mathrm{Cl}^{-}$and rainfall $(p>0.05)$ in Table 3, suggesting that $\mathrm{Na}^{+}$mainly existed in coarse particles and was readily removed by rainfall. As shown in Table 3, concentrations of $\mathrm{Na}^{+}$and $\mathrm{Cl}^{-}$were also negatively influenced by temperature and relatively humidity. Although $\mathrm{Mg}^{2+}$ is often treated 
Table 3. Correlation coefficients among major ions in aerosol and meteorological parameters.

\begin{tabular}{lrrrrrrrrrrrrrr}
\hline & $\mathrm{TSPs}$ & $\mathrm{Na}^{+}$ & $\mathrm{Cl}^{-}$ & $\mathrm{SO}_{4}^{2-}$ & $\mathrm{Ca}^{2+}$ & $\mathrm{Mg}^{2+}$ & $\mathrm{K}^{+}$ & $\mathrm{NH}_{4}^{+}$ & $\mathrm{NO}_{3}^{-}$ & $\mathrm{WS}$ & $T$ & $\mathrm{RH}$ & $R$ \\
\hline $\mathrm{TSPs}$ & 1 & $0.77^{* *}$ & $0.92^{* *}$ & $0.77^{* *}$ & $0.92^{* *}$ & $0.32^{* *}$ & $0.75^{* *}$ & -0.05 & $0.52^{* *}$ & $0.36^{* *}$ & $-0.47^{* *}$ & $-0.44^{* *}$ & -0.20 \\
$\mathrm{Na}^{+}$ & 1 & $0.91^{* *}$ & $0.69^{* *}$ & $0.72^{* *}$ & $0.57^{* *}$ & $0.78^{* *}$ & -0.03 & $0.48^{* *}$ & $0.44^{* *}$ & $-0.51^{* *}$ & $-0.46^{* *}$ & $-0.27^{*}$ \\
$\mathrm{Cl}^{-}$ & & & 1 & $0.71^{* *}$ & $0.83^{* *}$ & $0.49^{* *}$ & $0.77^{* *}$ & -0.04 & $0.45^{* *}$ & $0.43^{* *}$ & $-0.37^{* *}$ & $-0.36^{* *}$ & -0.19 \\
$\mathrm{SO}_{4}^{2-}$ & & & & 1 & $0.86^{* *}$ & $0.56^{* *}$ & $0.85^{* *}$ & $0.26^{*}$ & $0.87^{* *}$ & 0.04 & $-0.56^{* *}$ & $-0.58^{* *}$ & $-0.29^{*}$ \\
$\mathrm{Ca}^{2+}$ & & & & & 1 & $0.36^{* *}$ & $0.81^{* *}$ & -0.03 & $0.69^{* *}$ & 0.24 & $-0.51^{* *}$ & $-0.53^{* *}$ & $-0.27^{*}$ \\
$\mathrm{Mg}^{2+}$ & & & & & & 1 & $0.63^{* *}$ & $0.45^{* *}$ & $0.59^{* *}$ & 0.04 & -0.12 & -0.08 & -0.18 \\
$\mathrm{~K}^{+}$ & & & & & & & 1 & -0.18 & $0.72^{* *}$ & 0.15 & $-0.51^{* *}$ & $-0.45^{* *}$ & $-0.27^{*}$ \\
$\mathrm{NH}_{4}^{+}$ & & & & & & & & & 1 & $0.36^{* *}$ & -0.13 & -0.18 & 0.11 & -0.18 \\
$\mathrm{NO}_{3}^{-}$ & & & & & & & & & 1 & -0.05 & $-0.50^{* *}$ & $-0.50^{* *}$ & $-0.31^{* *}$ \\
\hline
\end{tabular}

** Correlation significant at 0.01 level (two-tailed), * significant at 0.05 level (two-tailed). WS: wind speed $\left(\mathrm{m} \mathrm{s}^{-1}\right) ; T$ : temperature $\left({ }^{\circ} \mathrm{C}\right) ; \mathrm{RH}$ : relative humidity $(\%) ; R$ : rainfall (mm $\left.\mathrm{h}^{-1}\right)$,

as crustal-derived ions and elements in continental studies (Zhang et al., 2015), its highest monthly average concentrations were in November at Yongxing Island, the same as $\mathrm{Na}^{+}$ and $\mathrm{Cl}^{-}$(Fig. 5). As shown in Fig. 5, Tables 1 and 2, similar trends and strong correlation were observed among $\mathrm{Na}^{+}, \mathrm{Cl}^{-}$ and $\mathrm{Mg}^{2+}$, and the ratios of $\mathrm{Mg}^{2+}$ to $\mathrm{Na}^{+}$in aerosols were close to that in seawater, suggesting that $\mathrm{Mg}^{2+}$ may mainly derive from sea salt rather than continental sources. However, there were no relationships between $\mathrm{Mg}^{2+}$ and wind speed, temperature, relatively humidity or rainfall (Table 2), in contrast to other ions, such as $\mathrm{Na}^{+}$and $\mathrm{Cl}^{-}$. These results reveal that $\mathrm{Mg}^{2+}$ has different behaviors in the marine atmosphere at Yongxing Island. The different behaviors of $\mathrm{Mg}^{2+}$ were also found in rainwater at Yongxing Island (Xiao et al., 2016).

As shown in Fig. 6, the highest monthly average concentrations of $\mathrm{Ca}^{2+}$ were in February. Its monthly trends were different from those of TSPs, $\mathrm{Na}^{+}$and $\mathrm{Cl}^{-}$, and the ratios of $\mathrm{Ca}^{2+}$ to $\mathrm{Na}^{+}$in aerosols were much higher than those in seawater (Table 2), suggesting that $\mathrm{Ca}^{2+}$ from terrestrial dust sources may be influenced by different factors. $\mathrm{Ca}^{2+}$ accounted for 10, 13 and $8 \%$ of total major ions in the cool, transition and warm seasons, respectively (Fig. 4). There was no correlation between $\mathrm{Ca}^{2+}$ and wind speed, in contrast to TSPs, $\mathrm{Na}^{+}$and $\mathrm{Cl}^{-}$(Table 3). However, there was a negative relationship between $\mathrm{Ca}^{2+}$ and rainfall $(p<0.05$; Table 3$)$. These results suggest that $\mathrm{Ca}^{2+}$ existed in coarse particles that can be readily removed by rainfall. Thus, a low mass concentration was observed for $\mathrm{Ca}^{2+}$ in the rainy (warm) season (Fig. 6), with a low percentage being in the warm season in Fig. 4.

$\mathrm{K}^{+}$concentrations were $0.42 \pm 0.23 \mu \mathrm{g} \mathrm{m}^{-3}$ in the cool season, $0.22 \pm 0.18 \mu \mathrm{g} \mathrm{m}^{-3}$ in warm season and $0.15 \pm 0.07 \mu \mathrm{g} \mathrm{m}^{-3}$ in the transition season at Yongxing, with the maximum monthly average concentrations in February and the minimum in July (Fig. 6). However, the lowest NSS-K ${ }^{+}$monthly average concentration was in August. The results suggest that NSS $\mathrm{K}^{+}$is derived from Chinese biomass/biofuel burning in the cool season (Lawrence and Lelieveld, 2010). Streets et al. (2003) computed that China contributes $25 \%$ of total biomass burning in Asia. Sites in Chinese coastal regions had higher $\mathrm{K}^{+}$and NSS- $\mathrm{K}^{+}$concentrations than those at Yongxing Island (Wang et al., 2006) were observed, further indicating that Chinese and other northeastern Asian regions' biomass/biofuel burning have a strong influence on atmospheric composition over the SCS.

Similar to $\mathrm{K}^{+}$, the highest monthly concentrations of $\mathrm{SO}_{4}^{2-}$ and $\mathrm{NO}_{3}^{-}$were observed in February, being at $13.08 \pm 9.04$ and $4.99 \pm 4.33 \mu \mathrm{g} \mathrm{m}^{-3}$, respectively (Fig. 6). As shown in the figure, $\mathrm{SO}_{4}^{2-}$ concentrations in the cool and warm seasons were $7.22 \pm 3.92$ and $3.26 \pm 1.26 \mu \mathrm{g} \mathrm{m}^{-3}$, respectively, accounting for 26 and $22 \%$ of total major ions, and $\mathrm{NO}_{3}^{-}$concentrations were $2.43 \pm 1.54$ and $1.30 \pm 0.64 \mu \mathrm{g} \mathrm{m}^{-3}$, accounting for 9 and $9 \%$. The $\mathrm{NH}_{4}^{+}$ showed maxima in the cool season and minima in the warm season, being $0.08 \pm 0.08$ and $0.04 \pm 0.03 \mu \mathrm{g} \mathrm{m}^{-3}$, respectively.

\subsubsection{Seasonal patterns over SCS and adjacent areas}

The spatial variability in seasonal patterns of the major inorganic ionic components at Yongxing Island and adjacent sites of the Acid Deposition Monitoring Network in East Asia (EANET) in 2011 is portrayed in Fig. 7. In general, total major inorganic ionic concentrations tended to be higher in cool seasons and lower in warm seasons to the north of Phnom Penh, including Phnom Penh, Hoa Binh, Hanoi, Hongwen, Hedo, Ogasawara and Yongxing Island, being consistent with previous studies (Boreddy and Kawamura, 2015; Wang et al., 2006; Xiao and Liu, 2004). There was no substantial seasonal variation at other sites of EANET, and there was no strong seasonal variation of rainfall there either. These results suggest that rainfall, wind patterns and anthropogenic activities influence the ionic seasonal variations (Lawrence and Lelieveld, 2010; Wang et al., 2006; Xiao et al., 2013; Xiao and Liu, 2004). Additionally, total major ionic concentrations were higher in the north than in the south, indicating more anthropogenic pollutants in the north, such as $\mathrm{SO}_{4}^{2-}$ and $\mathrm{NO}_{3}^{-}$(Lawrence and Lelieveld, 2010). As it is well known, the most densely populated regions in the north, in- 


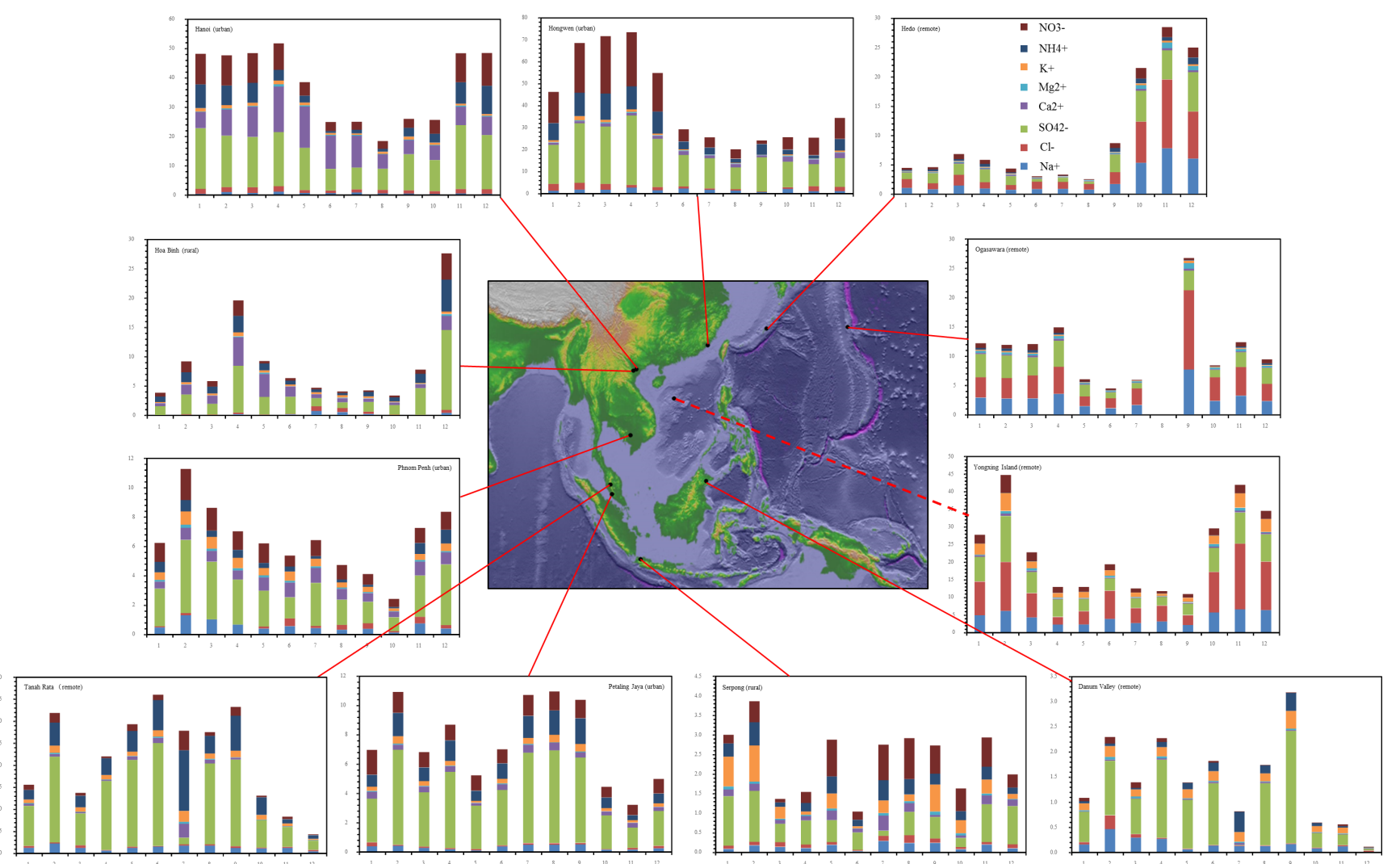

Figure 7. Comparison of aerosol chemical species between Yongxing Island and around the South China Sea (data from EANET).

cluding Hanoi, northeastern China and the Pearl River Delta of China, Korea and Japan release large amounts of pollutants (Lawrence and Lelieveld, 2010), which then transport to the SCS in the cool seasons (Fig. 1).

The total ionic concentrations were higher at the three islands than sites to the south of Phnom Penh. As shown in Fig. 7, relatively high concentrations of $\mathrm{Na}^{+}$and $\mathrm{Cl}^{-}$were found at those islands, suggesting that ions from sea salt had large contributions to total major ions, i.e., 52.8, 62.5 and $55.6 \%$ at Yongxing, Ogasawara and Hedo, respectively. This represents high mass concentrations of sea salt in the marine atmospheric aerosol. The highest concentrations of both $\mathrm{Na}^{+}$and $\mathrm{Cl}^{-}$appeared in November at Yongxing and Hedo islands, which were influenced by a strong northeast monsoon. The highest concentrations of both $\mathrm{Na}^{+}$and $\mathrm{Cl}^{-}$ were in September at Ogasawara Island, which were influenced by a strong southeast monsoon from the Pacific. The relationship between $\mathrm{Na}^{+}, \mathrm{Cl}^{-}$and wind speed at Yongxing $(p<0.01)$ is shown in Table 3. Other sites in Fig. 7 were also influenced by wind speed and winds directly from the ocean. However, the highest $\mathrm{Na}^{+}$and $\mathrm{Cl}^{-}$concentrations at some sites did not appear in the same month, e.g., at Hongwen, the highest concentrations of $\mathrm{Na}^{+}$were in April and the highest of $\mathrm{Cl}^{-}$were in January. Excess $\mathrm{Cl}^{-}$in January has been observed by anthropogenic sources in China (Duan et al., 2006).

The highest concentrations of $\mathrm{Mg}^{2+}$ were in the same months as $\mathrm{Na}^{+}$at most sites, indicating that $\mathrm{Mg}^{2+}$ may be from sea salt with $\mathrm{Na}^{+}$for almost all stations. The exceptions were at Hoa Binh and Tanah Rata with the maximum $\mathrm{Mg}^{2+}$ concentrations being in December and July, respectively. This suggests that $\mathrm{Mg}^{2+}$ originates from the crust rather than oceans (Xiao and Liu, 2004), or from both crust and ocean at these sites. Hoa Binh was influenced by the northeast monsoon, which carries strongly weathering crustal matters from the Chinese Yunnan-Guizhou Plateau karst (Hien et al., 2004; Xiao et al., 2013), and there was a strong relationship between $\mathrm{Mg}^{2+}$ and $\mathrm{Ca}^{2+}(R=0.7, p<0.05) . \mathrm{Ca}^{2+}$ had its highest concentrations in July at Phnom Penh, Tanah Rata, Petaling Jaya, Serpong and Danum Valley, all of which are located in the south of the SCS. In these regions, relatively little rainfall (rainfall data from EANET) and strong sunlight were observed in that month, leading to strong weathering that generated $\mathrm{Ca}^{2+}$. However, the highest $\mathrm{Ca}^{2+}$ concentrations were found at other sites in the cool season, during which there was much dust from northeastern Asia (Fig. S1; Boreddy and Kawamura, 2015; Y. Liu et al., 2014; Wang et al., 2011). This result is consistent with earlier studies (Boreddy and Kawamura, 2015; Cheng et al., 2000; Y. Liu 

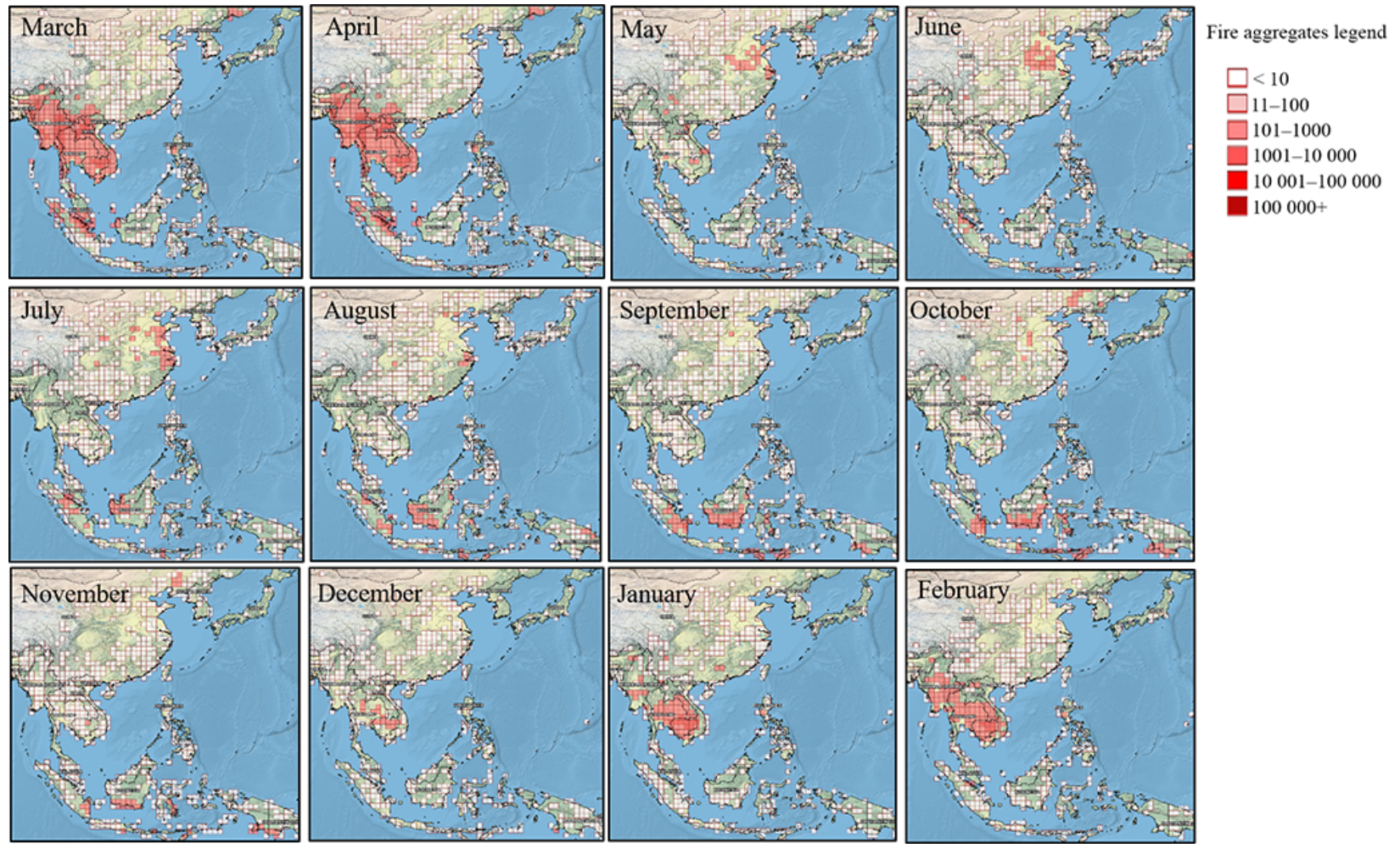

Figure 8. Fire spot data from MODIS global fire mapping from March 2014 to February 2015 around South China Sea (https://firms.modaps. eosdis.nasa.gov/firemap/).

et al., 2014; Zhao et al., 2015). The $\mathrm{Ca}^{2+}$ data also proved that Asian dust can affect northern SCS, but it is difficult for Asian dust to be transported to southern SCS (Fig. S1).

Figure 8 shows fire spot data from MODIS global fire mapping around the SCS during March 2014 to February 2015. Additionally, smoke surface concentrations every day in that period and region are shown in Fig. S1 in the Supplement. The fire spot and smoke data give information on seasonal variations of biomass burning around the SCS. This activity was strong from January to April in the west of the SCS, including Vietnam, Thailand and Laos, and between July and October in the south of the SCS, including Malaysia and Indonesia (Figs. 8 and S1). These data are consistent with other studies showing substantial monthly CO emissions from biomass burning during February-April and August-October in Southeast Asia, and February-May in southern China and Taiwan (Streets et al., 2003). $\mathrm{K}^{+}$is commonly used as a tracer of biomass and biofuel burning (Deng et al., 2011). As shown in Fig. 7, we found that the maximum $\mathrm{K}^{+}$was in the aforementioned months at most sites, suggesting that Asian biomass burning influenced the SCS region.

Fossil fuel combustion, industrial processes, biofuel burning, and agricultural and waste handling often generate large quantities of $\mathrm{SO}_{2}, \mathrm{NO}_{x}$ and $\mathrm{NH}_{3}$ in Asia (Lawrence and Lelieveld, 2010; Liu et al., 2013; Xiao et al., 2012a, 2014b, 2015), although natural emissions of $\mathrm{SO}_{2}$ and $\mathrm{NH}_{3}$ in- clude biomass burning, marine and soil biological processes (Streets et al., 2003; Altieri et al., 2014; Boreddy and Kawamura, 2015; Xiao et al., 2012a) and $\mathrm{NO}_{x}$ from those processes and lightning (Price et al., 1997; Xiao et al., 2015). In general, the three marine sites (Yongxing, Hedo, and Ogasawara islands) had smaller proportions of $\mathrm{SO}_{4}^{2-}, \mathrm{NO}_{3}^{-}$ and $\mathrm{NH}_{4}^{+}$than inland sites, with the three ions accounting for $\sim 35 \%$ at the three marine sites and up to $65 \%$ at the other sites. This indicates that anthropogenic contributions are smaller over remote open oceans than at continental sites. Figure 6 shows that the highest $\mathrm{SO}_{4}^{2-}, \mathrm{NO}_{3}^{-}$and $\mathrm{NH}_{4}^{+}$concentrations were found during the cool season in the north of Phnom Penh, including Phnom Penh, Hoa Binh, Hanoi, Hongwen, Hedo, Ogasawara and Yongxing, being consistent with total inorganic major ions. This indicates that the pollutants from northeastern Asia have a great impact on the northwestern Pacific. Figure S1 confirms these findings that pollutants from nature and anthropogenic activities effect the northwestern Pacific. We also found that most sites in the south of Phnom Penh had maximum $\mathrm{SO}_{4}^{2-}$ and $\mathrm{NO}_{3}^{-}$concentrations in the same months as the highest $\mathrm{K}^{+}$concentrations occurred, suggesting that biomass and biofuel burning are important sources for $\mathrm{SO}_{4}^{2-}$ and $\mathrm{NO}_{3}^{-}$in those regions. Lawrence and Lelieveld (2010) found that such burning was important in the emissions of $\mathrm{SO}_{4}^{2-}$ and $\mathrm{NO}_{3}^{-}$in southern Asia, whereas fossil fuel combustion and industrial 

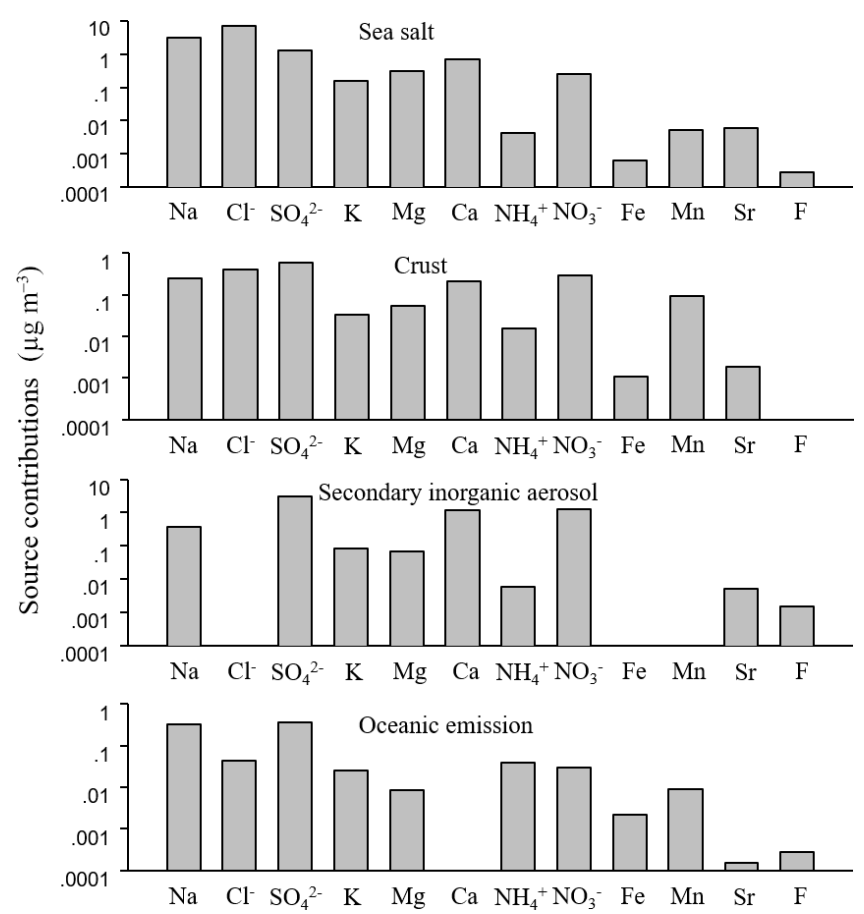

Figure 9. Profiles of five sources identified from the PMF 5.0 model, including sea salt (two species), crust, secondary inorganic aerosol and oceanic emission.

processes tended to be dominant in northern Asia (Xiao et al., 2015). However, maximum $\mathrm{NH}_{4}^{+}$concentrations at some sites (e.g., Petaling Jaya, Serpong, Danum Valley) were inconsistent with $\mathrm{SO}_{4}^{2-}$ and $\mathrm{NO}_{3}^{-}$. Moreover, there was no relationship between $\mathrm{SO}_{4}^{2-}$ or $\mathrm{NO}_{3}^{-}$and $\mathrm{NH}_{4}^{+}$at these sites in the south of Phnom Penh, including Phnom Penh and Yongxing Island (both $p>0.05$ ). The results are inconsistent with previous studies (Boreddy and Kawamura, 2015; Hsu et al., 2007; Wang et al., 2006; Xiao et al., 2013; Xiao and Liu, 2004). In the marine atmosphere, $\mathrm{SO}_{4}^{2-}$ and $\mathrm{NO}_{3}^{-}$are predominant in coarse particles (Boreddy and Kawamura, 2015; Xiao et al., 2015), whereas $\mathrm{NH}_{4}^{+}$is often predominant in fine particles and may exist in the form of $\left(\mathrm{NH}_{4}\right)_{2} \mathrm{SO}_{4}$ in their accumulation mode (Ooki et al., 2007; Ottley and Harrison, 1992).

\subsection{Source identification, apportionment and region}

Based on the PMF 5.0 model, five potential sources of atmospheric chemical components at Yongxing Island were identified: sea salt (two species), crust, secondary inorganic aerosol (SIA) and oceanic emission. Table 4 summarizes source apportionment of the relative contributions of each identified source to major ions. Figures 9 and 10 show the modeled source profiles and the time series of modeled concentrations for each identified main source.

Further, CWTs were plotted for TSPs and major ions (Fig. 11) to explore likely regional sources and transport

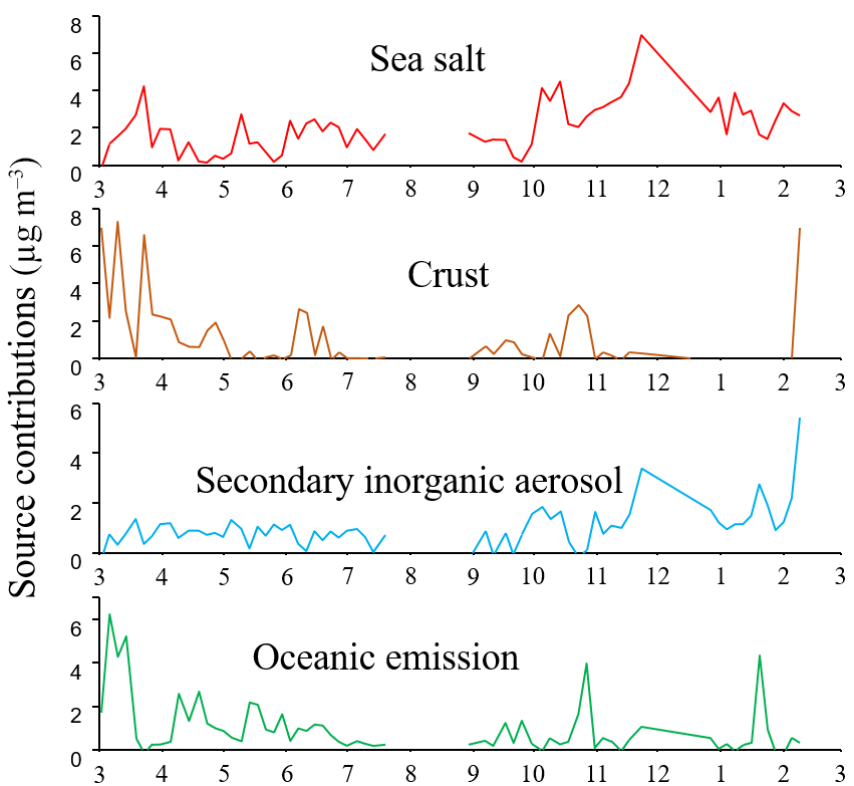

Figure 10. Time series contributions from each identified sources, including sea salt (two species), crust, secondary inorganic aerosol, and oceanic emission.

pathways for the island. Air masses at Yongxing Island had obvious unique and seasonal variations, from northeast of the island in the cool season, southwest in the warm season and southeast in the transition season (Fig. 11). This reveals that aerosol or chemical compositions at the island originated from different regions in different seasons (Figs. 1, 8, 11 and $\mathrm{S} 1)$. The air masses with high TSP concentrations were from China coastal regions bordering the Yellow and East China seas and northern South China (Fig. 11). This is consistent with the seasonal variations of TSP concentrations in Fig. 6. The average AOT over the northwestern Pacific (Fig. 1) confirmed this result. A relatively large average AOT was found over the northern SCS and East China Sea in the cool season, and Karimata Strait in the warm season (Fig. 1). But there was a relatively low average AOT over the entire SCS in the transition season (Fig. 1).

The first source, sea salt, generally has strong marine elements, such as $\mathrm{Na}^{+}\left(\mathrm{Cl}^{-}\right)$and $\mathrm{Mg}^{2+}$, in which $\mathrm{Na}^{+}$exists in super-micron size aerosols, whereas $\mathrm{Mg}^{2+}$ exists in sub-micron size aerosols (Moody et al., 2014). They contributed $77.4 \%\left(\mathrm{Na}^{+}\right), 93.9 \%\left(\mathrm{Cl}^{-}\right)$and $70.4 \%\left(\mathrm{Mg}^{2+}\right)$ from sea salt at Yongxing Island (Table 4). Although the CWT for $\mathrm{Mg}^{2+}$ was larger in the cool season and lower in the warm season, air masses with relatively high concentrations of $\mathrm{Mg}^{2+}$ originated offshore of China (Fig. 10). This further indicates that $\mathrm{Mg}^{2+}$ was mainly from sea salt. Other significant sources were crust, SIA and oceanic emission, with contributions $<10 \%$ for $\mathrm{Na}^{+}$and $\mathrm{Cl}^{-}$, and $<16 \%$ for $\mathrm{Mg}^{2+}$. According to data of rainwater at Yongxing Island, a part of $\mathrm{Na}^{+}$and $\mathrm{Cl}^{-}$could be from crust and produced by burning (Xiao et al., 2016). Coal combustion and biomass 
Table 4. Relative contributions (\%) for different major ions from potential five sources of TSPs at Yongxing Island over the year, based on PMF 5.0 model.

\begin{tabular}{lrrrrrrrr}
\hline Source & $\mathrm{Na}^{+}$ & $\mathrm{Cl}^{-}$ & $\mathrm{K}^{+}$ & $\mathrm{Ca}^{2+}$ & $\mathrm{Mg}^{2+}$ & $\mathrm{SO}_{4}^{2-}$ & $\mathrm{NO}_{3}^{-}$ & $\mathrm{NH}_{4}^{+}$ \\
\hline Sea salt (two species) & 77.4 & 93.9 & 53.2 & 33.9 & 70.4 & 24.0 & 13.1 & 6.7 \\
Crust & 6.1 & 5.5 & 10.8 & 9.8 & 11.9 & 11.5 & 15.9 & 23.6 \\
SIA & 8.8 & 0.0 & 27.7 & 56.3 & 15.8 & 57.5 & 69.5 & 9.1 \\
Oceanic emission & 7.7 & 0.6 & 8.3 & 0.0 & 2.0 & 6.9 & 1.6 & 60.5 \\
\hline
\end{tabular}
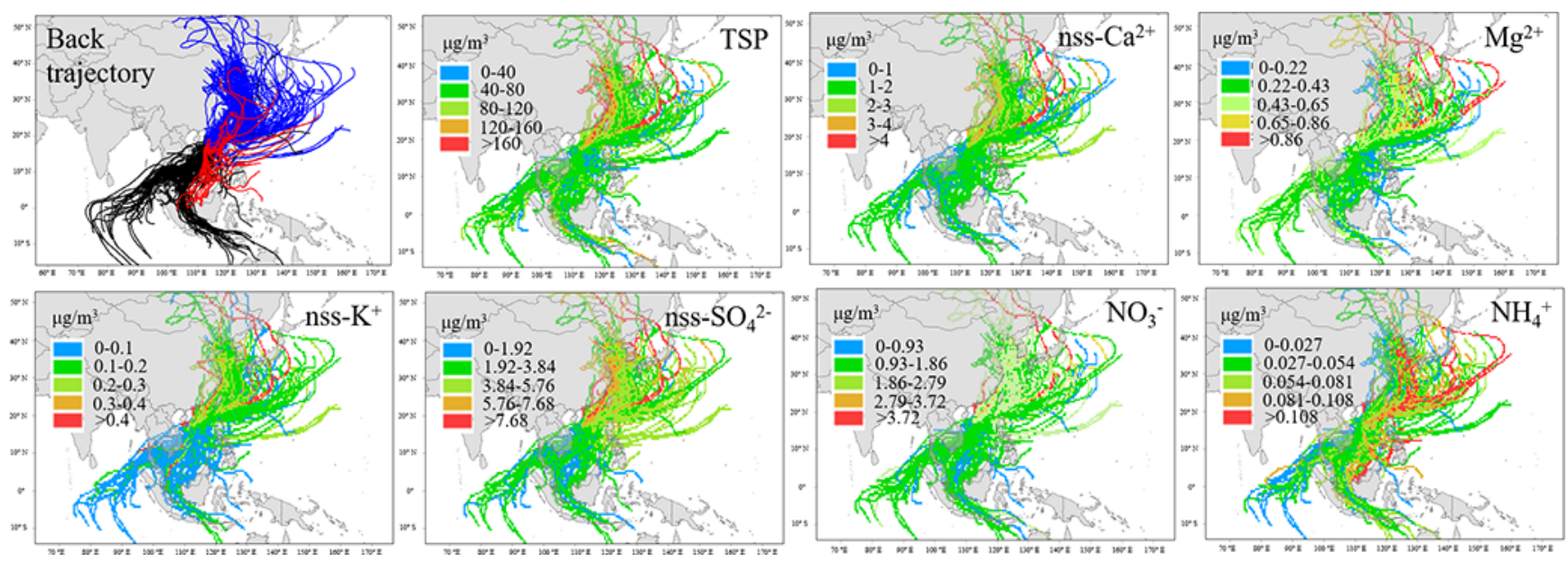

Figure 11. 10-day back trajectories of warm (black, June through September 2014), cool (blue, March and April 2014 and October 2014 through February 2015) seasons, and transition seasons (red, May 2014) at Yongxing Island. Additionally, CWT (concentration-weighted trajectory) plots for daily weighted-average concentrations of TSPs, $\mathrm{Ca}^{2+}, \mathrm{Mg}^{2+}, \mathrm{K}^{+}, \mathrm{SO}_{4}^{2-}, \mathrm{NO}_{3}^{-}$and $\mathrm{NH}_{4}^{+}$at Yongxing Island.

burning also produce $\mathrm{Na}^{+}$and $\mathrm{Cl}^{-}$(Liu et al., 2000; Tiwari et al., 2013; Zhang et al., 2015). Zhang et al. (2015) found that coal combustion was the most likely dominant source of $\mathrm{Cl}^{-}$in Beijing. The mole equivalent $\mathrm{Cl}^{-} / \mathrm{Na}^{+}$ratios were larger in the cool season than in the transition and warm seasons at Yongxing, indicating that the crust, fossil combustion, and biofuel and biomass burning affected $\mathrm{Na}^{+}$ and $\mathrm{Cl}^{-}$concentrations over the northwestern Pacific (Figs. 8 and S1). As shown in Table 3, there were strong relationships between $\mathrm{Na}^{+}\left(\mathrm{Cl}^{-}\right)$and $\mathrm{SO}_{4}^{2-}\left(\mathrm{Ca}^{2+}, \mathrm{K}^{+}\right)$, further proving that crust, fossil combustion and biomass burning can generate $\mathrm{Na}^{+}$and $\mathrm{Cl}^{-}$. Moreover, $\mathrm{NaCl}$ can react with acids such as $\mathrm{H}_{2} \mathrm{SO}_{4}, \mathrm{HNO}_{3}$ and $\mathrm{H}_{2} \mathrm{C}_{2} \mathrm{O}_{4}$, altering $\mathrm{Na}^{+}$and $\mathrm{Cl}^{-}$concentrations in the marine atmosphere and producing secondary chlorine-containing salt (Boreddy and Kawamura, 2015). Sea salt provided $\mathrm{K}^{+}, \mathrm{Ca}^{2+}$ and $\mathrm{SO}_{4}^{2-}$, constituting $53.2,33.9$ and $24.0 \%$, respectively. The ratios of $\mathrm{K}^{+} / \mathrm{Na}^{+}$, $\mathrm{Ca}^{2+} / \mathrm{Na}^{+}$and $\mathrm{SO}_{4}^{2-} / \mathrm{Na}^{+}$in Table 2 also indicate that part of them are from sea salt. The results are consistent with other studies (Boreddy and Kawamura, 2015).

The second source, crust, has substantial crustal elements $\mathrm{Ca}^{2+}$ and Mn (Fig. 9), which are tracers of crust (Suzuki and Tsunogai, 1988; Xiao et al., 2013; Xiao and Liu, 2004; Norris et al., 2014). However, $\mathrm{Ca}^{2+}$ from the crust, only had a contribution of $9.8 \%$ (Table 4). The result indicates that it is difficult for $\mathrm{Ca}^{2+}$ directly derived from crust to transport to open ocean. But CWTs for $\mathrm{Ca}^{2+}$ were larger in the cool season and lower in the warm season, indicating that dust from northeastern Asia influenced aerosol chemistry in the remote marine areas (Figs. 1, 11 and $\mathrm{S} 1$ ). The result suggests that when it reacts with $\mathrm{H}_{2} \mathrm{SO}_{4}$ and $\mathrm{HNO}_{3}$ to generate secondary inorganic aerosol, e.g., $\mathrm{CaSO}_{4}$ and $\mathrm{Ca}\left(\mathrm{NO}_{3}\right)_{2}$, it may transport to a longer distance.

The third source is relevant to secondary inorganic aerosol, which are typically characterized by remarkable $\mathrm{SO}_{4}^{2-}$ and $\mathrm{NO}_{3}^{-}$. They contributed 57.5 and $69.5 \%$ from SIA at Yongxing Island (Table 4) and good relationship between them was observed (Table 2). Fossil fuel (especially coal) combustion releases large amounts of $\mathrm{SO}_{2}$ and $\mathrm{NO}_{x}$ (Xiao et al., 2012b, 2014, 2015). Lawrence and Lelieveld (2010) attributed $61 \%$ of total $\mathrm{NO}_{x}$ and $77 \%$ of total $\mathrm{SO}_{2}$ emissions from fossil fuel combustion in southern Asia, and $76 \%$ of total $\mathrm{NO}_{x}$ and $75 \%$ of total $\mathrm{SO}_{2}$ in northern Asia, resulting in the transport of substantial secondary inorganic aerosols containing $\mathrm{SO}_{4}^{2-}$ and $\mathrm{NO}_{3}^{-}$to the SCS (Figs. 1, 11 and $\mathrm{S} 1$ ). As with TSPs and $\mathrm{Ca}^{2+}$, air masses from China, coastal regions had high $\mathrm{SO}_{4}^{2-}$ and $\mathrm{NO}_{3}^{-}$concentrations in the cool season (Fig. 11), owing to rapid economic development and great coal demand in the country, especially in its coastal re- 
gions (Lawrence and Lelieveld, 2010). Figure S1 also shows that $\mathrm{SO}_{4}^{2-}$ from central and eastern China reached coastal regions in the cool season. In Chinese coastal provinces, emission intensities of $\mathrm{SO}_{2}$ and $\mathrm{NO}_{x}$ were about 10 and 15 tons $\mathrm{km}^{-2}$, respectively, much higher than other Chinese provinces (China Environment Statistical Yearbook, 2014). Rapidly growing economies and high population densities in these regions (Kim et al., 2014) release pollutants that are transported to the northwestern Pacific. In the atmosphere, the products $\left(\mathrm{H}_{2} \mathrm{SO}_{4}\right.$ and $\left.\mathrm{HNO}_{3}\right)$ of $\mathrm{SO}_{2}$ and $\mathrm{NO}_{x}$ can easily combine alkaline ions, such as $\mathrm{Ca}^{2+}$ and $\mathrm{K}^{+}$(Xiao et al., 2013), in which $\mathrm{K}^{+}$is characterized as an effective tracer of biomass and biofuel burning aerosols (Zhang et al., 2015). As shown in Table 4, SIA had much bigger contributions of $56.3 \%$ to $\mathrm{Ca}^{2+}$ and $27.7 \%$ to $\mathrm{K}^{+}$. We found that there were strong relationships between $\mathrm{SO}_{4}^{2-}\left(\mathrm{NO}_{3}^{-}\right)$and $\mathrm{Ca}^{2+}\left(\mathrm{K}^{+}\right)$ (Table 3). These suggest that $\mathrm{SO}_{4}^{2-}$ and $\mathrm{NO}_{3}^{-}$changed source attribution of some alkaline ions to transport to open ocean. In this case, it is difficult to distinguish the $\mathrm{Ca}^{2+}$ and $\mathrm{K}^{+}$ sources using PMF model.

The fourth source is oceanic emissions, which released $\mathrm{NO}_{x}, \mathrm{NH}_{3}$ and oxidation of dimethyl sulfide (Altieri et al., 2014; Jickells et al., 2003; Boreddy and Kawamura, 2015; Phinney et al., 2006), with respective contributions of $1.6 \%$ to $\mathrm{NO}_{3}^{-}, 60.5 \%$ to $\mathrm{NH}_{4}^{+}$and $6.9 \%$ to $\mathrm{SO}_{4}^{2-}$ at Yongxing Island (Table 4). As shown in Fig. 11, air masses with high $\mathrm{NH}_{4}^{+}$concentrations were from remote open oceans such as the southeastern and northeastern SCS. There were relatively higher $\mathrm{NH}_{4}^{+}$concentrations in the cool season and lower values in the warm season at Yongxing Island (Fig. 6). These suggest that it is feasible for the ocean to be a $\mathrm{NH}_{4}^{+}$ source. Substantial $\mathrm{NH}_{x}$ may be released from degraded organic nitrogen-containing compounds and excretion from zooplankton in the ocean (Norman and Leck, 2005). Altieri et al. (2014) suggested that the efficient kinetics of ammonia evasion from surface seawater causes $\mathrm{NH}_{3}$ to accumulate in the marine atmosphere. The contribution of oceanic emission to $\mathrm{NH}_{4}^{+}$was much larger at Yongxing than at global marine atmospheric $\mathrm{NH}_{x}$ sources in the review of Duce et al. (2008), which showed $87.5 \%$ from anthropogenic sources. However, Altieri et al. (2014) found that the anthropogenic contribution was $<87.5 \%$ at Bermuda, an island in the North Atlantic Ocean (Fig. 5). Atmospheric $\mathrm{NH}_{x}$ is usually rapidly deposited near source regions and has a short residence time, about several hours in the marine boundary layer (Boreddy and Kawamura, 2015; Xiao et al., 2012a; Xiao and Liu, 2002). Thus, $\mathrm{NH}_{x}$ transportation from continental to remote sea sites is limited. Therefore, $\mathrm{NH}_{4}^{+}$in aerosol at Yongxing Island was possibly from oceanic emission, as being reported at other marine sites (Altieri et al., 2014; Jickells et al., 2003). DMS is the most abundant marine biogenic volatile sulfur emitted from the ocean surface to the atmosphere, and can be oxidized to $\mathrm{SO}_{4}^{2-}$ in the marine atmosphere (Phinney et al., 2006). Yang et al. (2015) reported that biogenic $\mathrm{SO}_{4}^{2-}$ from the Bohai and northern Yellow seas near China was 0.114$0.551 \mu \mathrm{g} \mathrm{m}^{-3}$, with an average of $0.247 \mu \mathrm{g} \mathrm{m}^{-3}$, accounting for $1.4 \%$ of $\mathrm{NSS} \mathrm{SO}_{4}^{2-}$. Biogenic $\mathrm{SO}_{4}^{2-}$ in the northern SCS was $\sim 1.2$ and $0.6 \mu \mathrm{g} \mathrm{m}^{-3}$ in summer and winter, respectively (Zhang et al., 2007), constituting $\sim 8$ and $12 \%$ of $\mathrm{NSS} \mathrm{SO}_{4}^{2-}$. CWTs for $\mathrm{SO}_{4}^{2-}$ in Fig. 11, also show some $\mathrm{SO}_{4}^{2-}$ were from marine biogenic source. Thus, natural sources had large contributions to marine atmospheric aerosols over the northwestern Pacific.

Figure 10 illustrates the time series of daily concentrations contributed by each identified source. In order to examine if the results are reasonable, we compared the modeled results of each source with the observed seasonal variations of the specific chemical species (Figs. 6 and 11). As shown in Fig. 9, the highest and lowest contributions of sea salt were in November-December and April-May, respectively, which are consistent with the seasonal variations of aerosol $\mathrm{Na}^{+}, \mathrm{Cl}^{-}$and $\mathrm{Mg}^{2+}$. For crust, the resulting time series show that it has a higher concentration in March 2014 and February 2015, relatively close to the observed values of $\mathrm{Ca}^{2+}$ and $\mathrm{K}^{+}$(Figs. 6 and 11). SIA has higher contributions from November 2014 to February 2015 and lower other months, which is also consistent with the observed and CWTs data of $\mathrm{SO}_{4}^{2-}$ and $\mathrm{NO}_{3}^{-}$shown in Figs. 6 and 11. This result is definitely related to the photochemistry that accounts for SIA formation (Zhang et al., 2013). The formed SIA species may not appear in their original emission sources (Zhang et al., 2013), such as coal combustion, biomass burning and crust. It is obvious that oceanic emissions have the highest contribution in March, and secondary highest in October, consistent with the seasonal change of $\mathrm{NH}_{4}^{+}$. The PMF and CWT modeled results seem to be promising because the corresponding time series of each source's contribution are very consistent with the observations.

\section{Conclusions}

Chemical compositions of 1 year of aerosol samples (TSPs) at Yongxing Island were investigated to help better understand their chemical characteristics, sources and transport pathways over the SCS. Sea salt $\left(\mathrm{Na}^{+}\right.$and $\left.\mathrm{Cl}^{-}\right)$had the greatest contribution to total major inorganic ions in aerosols at the island, followed by $\mathrm{SO}_{4}^{2-}, \mathrm{Ca}^{2+}, \mathrm{NO}_{3}^{-}, \mathrm{Mg}^{2+}, \mathrm{K}^{+}$ and $\mathrm{NH}_{4}^{+}$. The concentrations of TSPs and all major inorganic ions showed seasonal variations, with higher concentrations in the cool season and lower in the warm season, which was influenced by meteorological parameters (e.g., wind speed, temperature, relative humidity and rainfall) and air masses. Using PMF and CWT models, fire spot and AOT, we found that $\mathrm{Na}^{+}, \mathrm{Cl}^{-}$and $\mathrm{Mg}^{2+}$ were mainly derived from sea salt, $\mathrm{SO}_{4}^{2-}$ and $\mathrm{NO}_{3}^{-}$of secondary inorganic aerosol, which mainly came from fossil fuel combustion (especially coal combustion in the northern Asia). $\mathrm{NH}_{4}^{+}$was mainly from oceanic emission in the remote ocean. In summary, fossil fuel 
combustion seriously affected marine atmospheric aerosol chemical compositions over the SCS.

Data availability. All available data can be found in the Supplement.

\section{The Supplement related to this article is available online at doi:10.5194/acp-17-3199-2017-supplement.}

Competing interests. The authors declare that they have no conflict of interest.

Acknowledgements. This work was supported by the National Natural Science Foundation of China (grant nos. 41425014, 41663003 and 41203015), Strategic Priority Research Program of the Chinese Academy of Sciences (grant nos. XDA11030103 and XDA11020202), Doctoral Scientific Research Foundation of East China University of Technology (grant no. DHBK2015327), Research Foundation of Key Laboratory of Nuclear Resources and Environment (grant no. Z1609) and Scientific Research Foundation of East China University of Technology for Science and Technology Innovation Team (grant no. DHKT2015101).

Edited by: A. Petzold

Reviewed by: two anonymous referees

\section{References}

Altieri, K. E., Hastings, M. G., Peters, A. J., Oleynik, S., and Sigman, D. M.: Isotopic evidence for a marine ammonium source in rainwater at Bermuda, Global Biogeochem. Cy., 28, 1066-1080, 2014.

Arakaki, T., Azechi, S., Somada, Y., Ijyu, M., Nakaema, F., Hitomi, Y., Handa, D., Oshiro, Y., Miyagi, Y., and Ai, T.: Spatial and temporal variations of chemicals in the TSP aerosols simultaneously collected at three islands in Okinawa, Japan, Atmos. Environ., 97, 479-485, 2014.

Atwood, S. A., Reid, J. S., Kreidenweis, S. M., Cliff, S. S., Zhao, Y., Lin, N. H., Tsay, S. C., Chu, Y. C., and Westphal, D. L.: Size resolved measurements of springtime aerosol particles over the northern South China Sea, Atmos. Environ., 78, 134-143, 2013.

Balasubramanian, R., Karthikeyan, S., Potter, J., Wurl, O., and Durville, C.: Chemical characterization of aerosols in the equatorial atmosphere over the Indian Ocean, Atmos. Environ., 78, 268-276, 2013.

Boreddy, S. K. R. and Kawamura, K.: A 12-year observation of water-soluble ions in TSP aerosols collected at a remote marine location in the western North Pacific: an outflow region of Asian dust, Atmos. Chem. Phys., 15, 6437-6453, doi:10.5194/acp-156437-2015, 2015.

Carrillo, J. H., Hastings, M. G., Sigman, D. M., and Huebert, B. J.: Atmospheric deposition of inorganic and organic nitrogen and base cations in Hawaii, Global Biogeochem. Cy., 16, 1076, doi:10.1029/2002GB001892, 2002.
Cheng, I., Zhang, L., Blanchard, P., Dalziel, J., and Tordon, R.: Concentration-weighted trajectory approach to identifying potential sources of speciated atmospheric mercury at an urban coastal site in Nova Scotia, Canada, Atmos. Chem. Phys., 13, 6031-6048, doi:10.5194/acp-13-6031-2013, 2013.

Cheng, Z. L., Lam, K. S., Chan, L. Y., Wang, T., and Cheng, K. K.: Chemical characteristics of aerosols at coastal station in Hong Kong. I. Seasonal variation of major ions, halogens and mineral dusts between 1995 and 1996, Atmos. Environ., 34, 2771-2783, 2000.

Chin, M: Atmospheric Aerosol Properties and Climate Impacts, DIANE Publishing, 2009.

Claeys, M., Wang, W., Vermeylen, R., Kourtchev, I., Chi, X., Farhat, Y., Surratt, J. D., Gómez-González, Y., Sciare, J., and Maenhaut, W.: Chemical characterisation of marine aerosol at Amsterdam Island during the austral summer of 2006-2007, Aerosol Science, 41, 13-22, 2010.

Crippa, M., Canonaco, F., Slowik, J. G., El Haddad, I., DeCarlo, P. F., Mohr, C., Heringa, M. F., Chirico, R., Marchand, N., Temime-Roussel, B., Abidi, E., Poulain, L., Wiedensohler, A., Baltensperger, U., and Prévôt, A. S. H.: Primary and secondary organic aerosol origin by combined gas-particle phase source apportionment, Atmos. Chem. Phys., 13, 8411-8426, doi:10.5194/acp-13-8411-2013, 2013.

Cui, D. Y., Wang, J. T., Tan, L. J., and Dong, Z. Y.: Impact of atmospheric wet deposition on phytoplankton community structure in the South China Sea, Estuar. Coast. Shelf S., 173, 1-8, 2016.

Davidson, C. I., Phalen, R. F., and Solomon, P. A.: Airborne particulate matter and human health: a review, Aerosol Sci. Technol., 39, 737-749, 2005.

Duan, F. K., He, K. B., Ma, Y. L., Yang, F. M., Yu, X. C., Cadle, S. H., Chan, T., and Mulawa, P. A.: Concentration and chemical characteristics of $\mathrm{PM}_{2.5}$ in Beijing, China: 2001-2002, Sci. Total Environ., 355, 264-275, 2006.

Duce, R. A., Laroche, J., Altieri, K., Arrigo, K. R., Baker, A. R., Capone, D. G., Cornell, S., Dentener, F., Galloway, J., and Ganeshram, R. S.: Impacts of atmospheric anthropogenic nitrogen on the open ocean, Science, 320, 893-897, 2008.

Ebert, M., Weinbruch, S., Hoffmann, P., and Ortner, H. M.: Chemical characterization of North Sea aerosol particles, J. Aerosol Sci., 31, 613-632, 2000.

Hien, P. D., Bac, V. T., and Thinh, N.: PMF receptor modelling of fine and coarse $\mathrm{PM}_{10}$ in air masses governing monsoon conditions in Hanoi, northern Vietnam, Atmos. Environ., 38, 189-201, 2004.

Hsu, S. C., Liu, S. C., Kao, S. J., Jeng, W. L., Huang, Y. T., Tseng, C. M., Tsai, F., Tu, J. Y., and Yang, Y.: Water-soluble species in the marine aerosol from the northern South China Sea: High chloride depletion related to air pollution, J. Geophys. Res.-Atmos., 112, 216-229, 2007.

Jickells, T. D., Kelly, S. D., Baker, A. R., Biswas, K., Dennis, P. F., Spokes, L. J., Witt, M., and Yeatman, S. G.: Isotopic evidence for a marine ammonia source, Geophys. Res. Lett., 30, 359-376, 2003.

Jung, J., Furutani, H., and Uematsu, M.: Atmospheric inorganic nitrogen in marine aerosol and precipitation and its deposition to the North and South Pacific Oceans, J. Atmos. Chem., 68, 157$181,2012$. 
Keene, W. C., Pszenny, A. A. P, Galloway, J. N., and Hawley, M. E.: Sea-salt corrections and interpretation of constituent ratios in marine precipitation, J. Geophys. Res., 91, 6647-6657, 1986.

Kim, T. W., Lee, K., Duce, R., and Liss, P.: Impact of atmospheric nitrogen deposition on phytoplankton productivity in the South China Sea, Geophys. Res. Lett., 41, 3156-3162, 2014.

Kolb, C. E. and Worsnop, D. R.: ChemInform Abstract: Chemistry and Composition of Atmospheric Aerosol Particles, Annu. Rev. Phys. Chem., 44, 471-491, 2013.

Kumar, A., Sudheer, A. K., and Sarin, M. M.: Chemical characteristics of aerosols in MABL of Bay of Bengal and Arabian Sea during spring inter-monsoon: A comparative study, J. Earth Syst. Sci., 117, 325-332, 2008.

Lawrence, M. G. and Lelieveld, J.: Atmospheric pollutant outflow from southern Asia: a review, Atmos. Chem. Phys., 10, 1101711096, doi:10.5194/acp-10-11017-2010, 2010.

Liu, P. F., Zhao, C. S., Göbel, T., Hallbauer, E., Nowak, A., Ran, L., Xu, W. Y., Deng, Z. Z., Ma, N., Mildenberger, K., Henning, S., Stratmann, F., and Wiedensohler, A.: Hygroscopic properties of aerosol particles at high relative humidity and their diurnal variations in the North China Plain, Atmos. Chem. Phys., 11, 3479-3494, doi:10.5194/acp-11-3479-2011, 2011.

Liu, S., Chen, M., and Zhuang, Q: Aerosol effects on global land surface energy fluxes during 2003-2010, Geophys. Res. Lett., 41, 7875-7881, doi:10.1002/2014GL061640, 2014.

Liu, X., Espen, P. V., Adams, F., Cafmeyer, J., and Maenhaut, W.: Biomass Burning in Southern Africa: Individual Particle Characterization of Atmospheric Aerosols and Savanna Fire Samples, J. Atmos. Chem., 36, 135-155, 2000.

Liu, X., Zhang, Y., Han, W., Tang, A., Shen, J., Cui, Z., Vitousek, P., Erisman, J. W., Goulding, K., and Christie, P.: Enhanced nitrogen deposition over China, Nature, 494, 459-462, 2013.

Liu, Y., Sun, L., Zhou, X., Luo, Y., Huang, W., Yang, C., Wang, Y., and Huang, T.: A 1400-year terrigenous dust record on a coral island in South China Sea, Scientific Reports, 4, 4994-4994, 2014.

Moody, J. L., Keene, W. C., Cooper, O. R., Voss, K. J., Aryal, R., Eckhardt, S., Holben, B., Maben, J. R., Izaguirre, M. A., and Galloway, J. N.: Flow climatology for physicochemical properties of dichotomous aerosol over the western North Atlantic Ocean at Bermuda, Atmos. Chem. Phys., 14, 691-717, doi:10.5194/acp14-691-2014, 2014.

Norman, M. and Leck, C.: Distribution of marine boundary layer ammonia over the Atlantic and Indian Oceans during the Aerosols99 cruise, J. Geophys. Res., 110, D16302, doi:10.1029/2005JD005866, 2005.

Norris, G. A., Duvall, R., Brown, S. G., and Bai, S.: EPA Positive Matrix Factorization (PMF) 5.0 fundamentals and User Guide Prepared for the US Environmental Protection Agency Office of Research and Development, Washington, DC, DC EPA/600/R14/108, 2014

Okuda, T., Tenmoku, M., Kato, J., Mori, J., Sato, T., Yokochi, R., and Tanaka, S.: Long-term observation of trace metal concentration in aerosols at a remote island, Rishiri, Japan by using inductively coupled plasma mass spectrometry equipped with laser ablation, Water Air Soil Poll., 174, 3-17, 2006.

Ooki, A., Uematsu, M., and Noriki, S.: Size-resolved sulfate and ammonium measurements in marine boundary layer over the North and South Pacific, Atmos. Environ., 41, 81-91, 2007.
Ottley, C. J. and Harrison, R. M.: The spatial distribution and particle size of some inorganic nitrogen, sulphur and chlorine species over the North Sea, Atmos. Environ., 26, 1689-1699, 1992.

Pavuluri, C. M., Kawamura, K., and Fu, P. Q.: Atmospheric chemistry of nitrogenous aerosols in northeastern Asia: biological sources and secondary formation, Atmos. Chem. Phys., 15, 9883-9896, doi:10.5194/acp-15-9883-2015, 2015.

Phinney, L., Leaitch, W. R., Lohmann, U., Boudries, H., Worsnop, D. R., Jayne, J. T., Toom-Sauntry, D., Wadleigh, M., Sharma, S., and Shantz, N.: Characterization of the aerosol over the subarctic north east Pacific Ocean, Deep Sea Res. Pt. II, 53, 2410 2433, 2006.

Price, C., Penner, J., and Prather, M.: $\mathrm{NO}_{x}$ from lightning: 1. Global distribution based on lightning physics, J. Geophys. Res.-Atmos., 102, 5929-5942, 1997.

Rinaldi, M., Decesari, S., Finessi, E., Giulianelli, L., Carbone, C., Fuzzi, S., O’Dowd, C., Ceburnis, D., and Facchini, M. C.: Primary and secondary organic marine aerosol and oceanic biological activity: Recent results and new perspectives for future studies, Advances in Meteorology, 2010, 1-10, doi:10.1155/2010/310682, 2010.

Steyn, D. G. and Chaumerliac, N.: Air Pollution Modeling and its Application XXIV, Utrecht, Springer, 2016.

Streets, D. G., Yarber, K. F., Woo, J. H., and Carmichael, G. R.: Biomass burning in Asia: annual and seasonal estimates and atmospheric emissions, Global Biogeochem. Cy., 17, 1759-1768, 2003.

Suzuki, T. and Tsunogai, S.: Origin of calcium in aerosols over the western north Pacific, J. Atmos. Chem., 6, 363-374, 1988.

Tiwari, S., Pervez, S., Cinzia, P., Bisht, D. S., Kumar, A., and Chate, D.: Chemical characterization of atmospheric particulate matter in Delhi, India, part II: Source apportionment studies using PMF 3.0, Sustainable Environment Research, 23, 295-306, 2013.

Wang, L., Qi, J. H., Shi, J. H., Chen, X. J., and Gao, H. W.: Source apportionment of particulate pollutants in the atmosphere over the Northern Yellow Sea, Atmos. Environ., 70, 425-434, 2013.

Wang, S. H., Tsay, S. C., Lin, N. H., Hsu, N. C., Bell, S. W., Li, C., Ji, Q., Jeong, M. J., Hansell, R. A., and Welton, E. J.: First detailed observations of long-range transported dust over the northern South China Sea, Atmos. Environ., 45, 4804-4808, 2011.

Wang, S. H., Tsay, S. C., Lin, N. H., Chang, S. C., Li, C., Welton, E. J., Holben, B. N., Hsu, N. C., Lau, W. K. M., and Lolli, S.: Origin, transport, and vertical distribution of atmospheric pollutants over the northern South China Sea during the 7-SEAS/Dongsha Experiment, Atmos. Environ., 78, 124-133, 2013.

Wang, Y., Zhuang, G., Zhang, X., Huang, K., Xu, C., Tang, A., Chen, J., and An, Z.: The ion chemistry, seasonal cycle, and sources of $\mathrm{PM}_{2.5}$ and TSP aerosol in Shanghai, Atmos. Environ., 40, 2935-2952, 2006

Wang, Y. Q., Zhang, X. Y., and Draxler, R.: TrajStat: GIS-based software that uses various trajectory statistical analysis methods to identify potential sources from long-term air pollution measurement data, Environ. Modell. Softw., 24, 938-939, 2009.

Xiao, H., Xiao, H., Long, A., and Wang, Y.: Who controls the monthly variations of $\mathrm{NH}_{4}^{+}$nitrogen isotope composition in precipitation?, Atmos. Environ., 54, 201-206, 2012a.

Xiao, H., Xiao, H., Long, A., and Wang, Y.: Nitrogen isotopic composition and source of nitrate in precipitation at Guiyang, Acta 
Scientiae Circumstantiae, 32, 940-945, 2012b (Chinese with English Abstract).

Xiao, H., Xiao, H., Long, A., Wang, Y., and Liu, C.: Chemical composition and source apportionment of rainwater at Guiyang, SW China, J. Atmos. Chem., 70, 269-281, 2013.

Xiao, H., Xiao, H., Long, A., Wang, Y., and Liu, C.: Sources and meteorological factors that control seasonal variation of $\delta^{34} \mathrm{~S}$ values in rainwater, Atmos. Res., 149, 154-165, 2014a.

Xiao, H., Long, A., Xie, L., Xiao, H., and Liu, C.: Chemical characteristics of precipitation in South China Sea, Environm. Sci., 35, 475-480, 2014b (Chinese with English Abstract).

Xiao, H., Xie, L., Long, A., Ye, F., Pan, Y., Li, D., Long, Z., Chen, L., Xiao, H., and Liu, C.: Use of isotopic compositions of nitrate in TSP to identify sources and chemistry in South China Sea, Atmos. Environ., 109, 70-78, 2015.

Xiao, H., Xiao, H., Zhang, Z., Wang, Y., Long, A., and Liu, C.: Chemical characteristics and source apportionment sources of precipitation in Yongxing Island, China Environmental Science, 36, 3237-3244, 2016 (Chinese with English Abstract).

Xiao, H. Y. and Liu, C. Q.: Sources of nitrogen and sulfur in wet deposition at Guiyang, southwest China, Atmos. Environ., 36, 5121-5130, 2002.

Xiao, H. Y. and Liu, C. Q.: Chemical characteristics of watersoluble components in TSP over Guiyang, SW China, 2003, Atmos. Environ., 38, 6297-6306, 2004.

Yang, G., Zhang, S., Zhang, H., Yang, J. and Liu, C.: Distribution of biogenic sulfur in the Bohai Sea and northern Yellow Sea and its contribution to atmospheric sulfate aerosol in the late fall, Mar. Chem., 169, 23-32, 2015.
Zhang, M., Chen, J. M., Wang, T., Cheng, T. T., Lin, L., Bhatia, R. S., and Havey, M.: Chemical characterization of aerosols over the Atlantic Ocean and the Pacific Ocean during two cruises in 2007 and 2008, J. Geophys. Res., 115, 1842-1851, 2010.

Zhang, Q., Jimenez, J. L., Canagaratna, M. R., Ulbrich, I. M., Ng, N. L., Worsnop, D. R., and Sun, Y. L.: Understanding atmospheric organic aerosols via factor analysis of aerosol mass spectrometry: a review, Anal. Bioanal. Chem., 401, 3045-3067, 2011.

Zhang, R., Jing, J., Tao, J., Hsu, S.-C., Wang, G., Cao, J., Lee, C. S. L., Zhu, L., Chen, Z., Zhao, Y., and Shen, Z.: Chemical characterization and source apportionment of $\mathrm{PM}_{2.5}$ in Beijing: seasonal perspective, Atmos. Chem. Phys., 13, 7053-7074, doi:10.5194/acp-13-7053-2013, 2013.

Zhang, X., Zhuang, G., Guo, J., Yin, K., and Zhang, P.: Characterization of aerosol over the Northern South China Sea during two cruises in 2003, Atmos. Environ., 41, 7821-7836, 2007.

Zhang, X. Y., Wang, Y. Q., Niu, T., Zhang, X. C., Gong, S. L., Zhang, Y. M., and Sun, J. Y.: Atmospheric aerosol compositions in China: spatial/temporal variability, chemical signature, regional haze distribution and comparisons with global aerosols, Atmos. Chem. Phys., 12, 779-799, doi:10.5194/acp12-779-2012, 2012.

Zhao, R., Han, B., Lu, B., Zhang, N., Zhu, L. and Bai, Z.: Element composition and source apportionment of atmospheric aerosols over the China Sea, Atmospheric Pollution Research, 6, 191201, 2015. 